OECD Economics Department Working Papers No. 397

Saving Behaviour and the Effectiveness

of Fiscal Policy

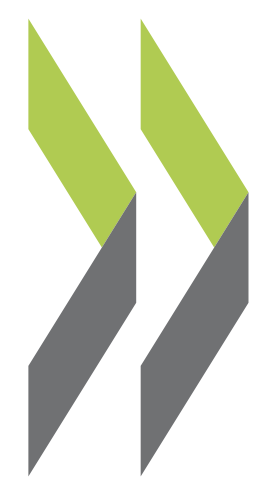

\section{Luiz de Mello,}

Per Mathis Kongsrud, Robert Price 
Organisation de Coopération et de Développement Economiques

Organisation for Economic Co-operation and Development

13-Jul-2004

ECONOMICS DEPARTMENT

English text only

SAVING BEHAVIOUR AND THE EFFECTIVENESS OF FISCAL POLICY

ECONOMICS DEPARTMENT WORKING PAPERS NO. 397

By Luiz de Mello, Per Mathis Kongsrud and Robert Price

All Economics Department Working Papers are now available through OECD's Internet Web site at http://www.oecd.org/eco 


\section{ABSTRACT/RÉSUMÉ \\ Saving behaviour and the effectiveness of fiscal policy}

This paper examines the extent to which fiscal policy actions may be offset by simultaneous, anticipatory changes in private saving, as well as the determinants of that offset. The conditions under which private agents will engage in forward-looking consumption-smoothing behaviour are quite strict and unlikely to hold fully in practice. However, based on a sample of at most 21 OECD countries spanning the period 1970-2002, there is strong evidence of partial, yet substantial, offsetting movements in aggregate private and public saving. The overall offset is estimated at between about one-third and one-half, depending on model specification, and applies both to public consumption and revenue shifts. This is consistent with a marked degree of anticipatory private sector behaviour, insofar as the ex ante saving "leakage" embedded in the pure Keynesian or IS/LM type models would be expected to be smaller and apply only to revenues and transfers. Wealth effects, as in the case of rising equity and housing prices, are found to have an important complementary impact on saving, usually in reinforcing the direct saving offset. Initial conditions, as reflected in debt/GDP ratios are also found to influence the size of the offset.

JEL classification: E21, H30, C33.

Keywords: Fiscal policy, private saving, Ricardian equivalence.

$$
* * * * * *
$$

\section{Comportement d'économie et l'efficacité de la politique fiscale}

Cet article examine dans quelle mesure la politique budgétaire discrétionnaire peut être compensée par des mouvements simultanés et anticipés de l'épargne privée. Il étudie aussi les déterminants de cette compensation. Les conditions sous lesquelles les agents économiques privés lisseraient leur consommation dans le temps apparaissent difficilement applicables en pratique. Cependant, sur la base d'un échantillon d'au plus 21 pays de l'OCDE couvrant la période allant de 1970 à 2002, les résultats de cette étude indiquent une compensation partielle, bien que substantielle, des mouvements de l'épargne privée et publique agrégées. L'estimation de la compensation globale varie entre un tiers et un demi selon la spécification du modèle et s'applique tant à la consommation publique qu'aux recettes. Ce résultat est compatible avec un comportement d'anticipation très accusé de l'épargne privée dans la mesure où les fuites ex ante d'épargne incorporées dans les modèles Keynésiens purs ou du type IS/LM sont supposées plus faibles et ne s'appliqueraient qu'aux recettes et aux transferts. Les résultats indiquent que les effets de richesse, provenant de l'augmentation des prix des actions et des logements, ont une incidence complémentaire importante sur l'épargne. Les conditions initiales, reflétées par le ratio dette sur PIB, affectent la taille de la compensation.

Classification JEL : E21, H30, C33.

Mot clés : politique budgétaire, épargne privée, équivalence ricardienne.

\section{Copyright OECD, 2004}

Applications for permission to reproduce or translate all, or part of, this material should be made to : Head of Publications Service, OECD, 2 rue André-Pascal, 75775 Paris Cedex 16, France. 


\section{TABLE OF CONTENTS}

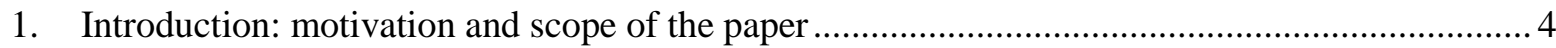

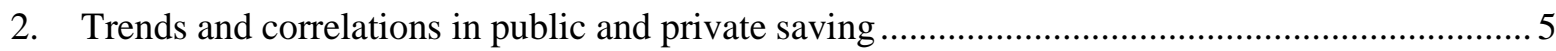

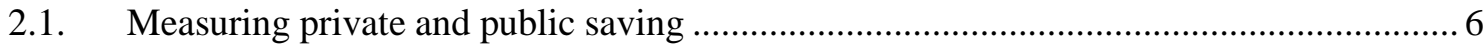

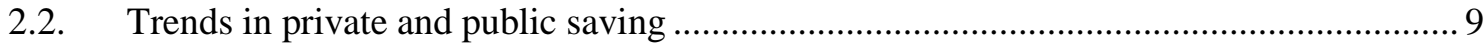

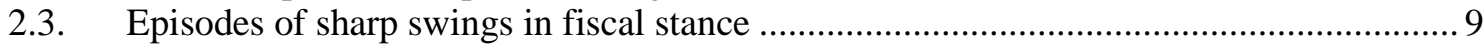

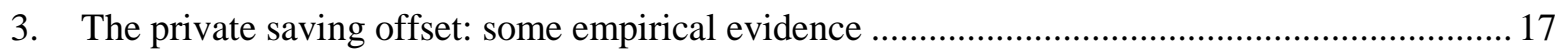

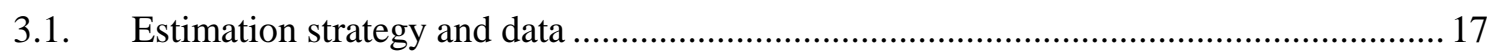

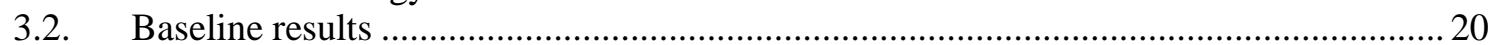

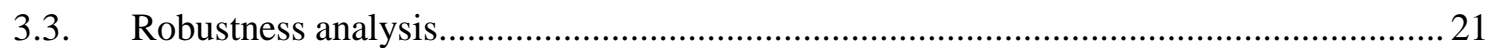

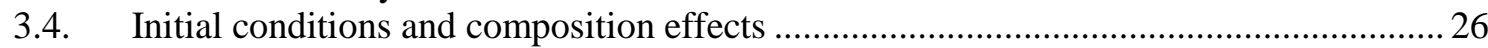

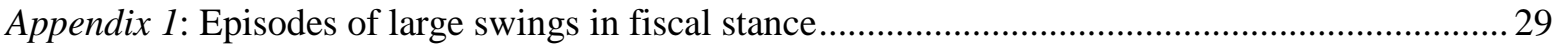

Appendix 2: Descriptive statistics and robustness analysis tables .................................................... 33

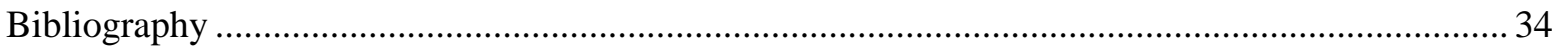

\section{Boxes}

Box 1. Private saving responses to budget deficits

Box 2. Private saving equations: conventional control variables

\section{Tables}

1. Sensitivity of private saving to fiscal stance: error-correction models

2. Sensitivity of private saving to fiscal stance: partial equilibrium models

3. Sensitivity of private saving to fiscal stance: composition effects and initial conditions

A2.1 Descriptive statistics

A2.2 Sensitivity of private saving to fiscal stance: alternative models

\section{Figures}

1. Private and public saving: deviations from averages

2. Private and public saving: raw correlations

3. $\quad$ Change in private and public saving

4. Public saving: inflation adjustment

5. Public debt and net financial wealth in selected OECD countries

A1. Episodes of large swings in fiscal stance in selected OECD countries 


\title{
SAVING BEHAVIOUR AND THE EFFECTIVINESS OF FISCAL POLICY
}

\author{
Luiz de Mello, Per Mathis Kongsrud and Robert Price ${ }^{1}$
}

\section{Introduction: motivation and scope of the paper}

1. The short-run effect of fiscal policy on aggregate demand will be damped if changes in fiscal stance are partially offset by simultaneous changes in private saving. This paper examines the possible extent of such offsets, focusing on "Ricardian equivalence" effects, i.e. saving behaviour that is caused when economic agents discount the higher taxes which will be needed to pay for government borrowing ("tax discounting"). The conditions under which co-movements in private and pubic saving would be fully offsetting are quite strict and unlikely to be realised in practice: they include, for example, an infinite time horizon and the absence of credit constraints for all segments of the population. However, even though conscious tax discounting may be rare, experience suggests that fiscal imbalances may be associated with offsetting movements in private saving, apparently related to uncertainties about the effects of tax changes on "permanent income", related to doubts about the sustainability of fiscal policies and the consequent need to insure against future tax surprises. Depending on their extent, such responses raise important issues for policy-makers.

2. In attempting to identify direct offsetting effects of budget deficits on saving based on tax discounting, the analysis has to confront the problem that changes in fiscal actions may, in principle, be offset by private saving responses through a variety of channels. In the standard IS/LM model this may occur ex ante because the marginal propensity to consume out of disposable income - and hence out of taxes and transfers - is less than one, and ex post, or indirectly, via higher interest rates and/or inflation, which cause financial "crowding out". In the latter case, portfolio considerations imply that fiscal policy shifts may have significant effects on household saving via changes in real and financial wealth. Some of these may derive directly from budget actions themselves, while others may result from contemporaneous non-fiscal developments, particularly monetary policy and exchange rate movements. The paper attempts to separate these other channels of influence on saving from the direct expectations-generated private/public saving offset, while looking at the conditions which may affect its magnitude. These include, most importantly, "starting point" considerations linked to the existing level of government indebtedness, and the role of composition effects.

3. The structure and method of the paper are as follows. Section 2 describes trends in public and private saving, identifying the possible channels through which agents respond to changes in fiscal stance. Several episodes of sizeable fiscal expansions and contractions are examined in detail. Section 3 estimates the magnitude of private saving offsets, controlling for other determinants of private saving, including, importantly, household wealth.

1. The research presented in this paper was conducted in the General Economic Analysis Division of the Economics Department. The authors wish to thank Jean-Philippe Cotis, Jørgen Elmeskov, Mike Feiner, Vincent Koen, Alain de Serres, and other members of the Economics Department for useful comments and discussions. They also thank Chantal Nicq and Christophe André for technical assistance, and Anne Eggimann and Sarah Kennedy for secretarial assistance. 
4. The main findings are as follows:

- The evidence of partial, yet substantial, offsetting movements in private and public saving is strong and consistent across countries. The overall offset is estimated at between about one-third and one-half, depending on model specification. This is consistent with a marked degree of anticipatory behaviour insofar as the saving offset applies both to public consumption and revenue shifts, whereas the pure Keynesian pre-multiplier saving "leakage" (equal to the marginal propensity to save) would be expected to be smaller and apply only to revenues and, to a lesser degree, transfers.

- Public investment does not elicit an offsetting saving response, consistent with both a Keynesian IS/LM framework and a permanent income one, where such investment may be deemed to yield either a financial rate of return or a social return, accruing to future tax-payers.

- Wealth effects, as in the case of rising equity and housing prices, have an important impact on the saving offset, reinforcing the direct saving offset in situations of unsustainable fiscal expansion and subsequent consolidation.

- Initial conditions, as reflected in the level of public indebtedness, influence the size of the private saving offset. For the whole period and country sample, private saving offsets appear to have been somewhat lower at higher levels of indebtedness, this phenomenon being consistent with the association of high debt with high levels of the "inflation tax" early in the period.

- The revenue/expenditure composition of the fiscal shift matters for the private saving offset. Private saving appears to respond in relatively equal proportion to changes in current revenue and expenditure, but public investment does not elicit an offsetting saving response.

\section{Trends and correlations in public and private saving}

5. This section first provides a brief discussion of the conceptual problems related to the measurement of private and public saving offsets. The conditions for strict debt neutrality, where movements in private and public saving are fully offsetting, are difficult to meet (see Box 1), while measuring the extent of the offset encounters problems of reverse causality. It then summarises trends in, and correlations between, public and private saving in selected OECD countries since the early 1970s. The approach is initially mainly descriptive, and does not purport to separate Ricardian responses from other influences affecting private saving. Aggregate, ex post saving patterns will reflect the complex responses to interrelated factors. A number of illustrative episodes are discussed in this regard. A more comprehensive and quantitative analysis, taking systematic account of other factors affecting private saving developments, is presented in Section 3.

\section{Box 1. Private saving responses to budget deficits}

According to the life cycle/permanent income hypothesis, households make spending decisions based on lifetime wealth, which incorporates expectations about future income, rather than on current disposable income. Linked expressly to fiscal policy and the issuance of government debt to finance public consumption, together with an infinite planning horizon based on the bequest motive, this leads to the concept of debt neutrality (Ricardian equivalence). Forward-looking private agents will, under certain conditions, fully internalise the fact that, to satisfy the government's intertemporal budget constraint, borrowing implies higher future debt service and, hence, deferred taxation (tax discounting). In this case, the impact of fiscal policy is summarized by the path of expenditures, while the timing of taxes -- as implied by budget deficits -- has no effect on the economy. ${ }^{1}$ 
The existence of Ricardian equivalence has been much debated, both in theoretical and empirical work. ${ }^{2}$ There $^{2}$ are strong theoretical objections to the existence of completely offsetting movements in private saving in response to changes in the timing of taxes, focused on the relatively strict conditions underlying the model. These include the requirement of a perfect credit market, non-distortionary taxes, and certainty about future taxes, income, and other variables. Also, current consumption decisions need to be based on infinite planning horizons, with positive transfers to future generations based on altruism. In general, these assumptions cannot be expected to hold. Nonetheless, significant, yet partial, offsetting effects may exist and the practical relevance of Ricardian equivalence becomes an empirical issue. Empirical validation of debt neutrality is constrained by the difficulty to test the validity of the different postulates on which the theoretical model rests and to disentangle all the channels through which offsetting movements in private and public saving may take place, regardless of whether debt neutrality holds.

1. The postulate that the timing of taxes has no real effects on the economy is in particular linked to a seminal paper by Barro (1974). See also Barro (1989).

2. For recent surveys see, for example, Seater (1985, 1993), Elmendorf and Mankiw (1999), Hemming et al. (2002), and Ricciuti (2003).

\subsection{Measuring private and public saving}

6. The measurement of private and public saving is fraught with conceptual problems. The treatment of capital gains, inflation, the aggregation of household and corporate saving, and the classification of spending between capital and current, are especially relevant.

\subsubsection{The treatment of capital gains}

7. The decline in private saving rates in some OECD countries in the second half of the 1990s was due not just to the rise in private consumption financed by the realisation of capital gains associated with the asset price boom but, to a large extent, reflected to some extent measurement issues related to the treatment of capital gains, and the taxes paid on them, in the National Accounts. ${ }^{2}$ National Accounts only treat as income those revenues that are generated from the current production flow, thereby ignoring stock revaluation effects. However, while realised capital gains are not included in personal income, taxes paid on them are recorded as negative personal income and government revenue. ${ }^{3}$ This implies an apparent shift of saving from households to the government when substantial gains occur in the private sector, thus inducing a spurious negative correlation between public and private saving, even in the absence of a behavioural response to private capital gains or losses (OECD, 2003b; de Serres and Pelgrin, 2003). ${ }^{4}$

2. In the United States, for example, the fall in the private saving rate in the 1990s is much lower if income is adjusted to include realised capital gains net of taxes (OECD, 2001a). See also de Serres and Pelgrin (2003), for further discussion.

3. Taxes on capital gains are not the only taxes that are classified in the National Accounts as taxes on income, while their tax bases are not treated as such. Revenue from taxes on property and wealth are, however, relatively stable from year to year.

4. In Finland, for example, the household saving rate more than halved during 1993-2001 (a decline of more than 2 percentage points), while it was more or less unchanged over the period when including realised capital gains (OECD, 2003b). Similarly, realised capital gains reached 9 per cent of US disposable income in 2000. As a consequence, taxes paid on those gains lowered the National Accounts measure of personal saving by around 2.5 percentage point in that year, at the benefit of government saving (OECD, 2001a). 
8. The risk of overestimating the magnitude of the private saving offset could make a case for recording realised capital gains as saving. ${ }^{5}$ This is, however, not without problems. First, capital gains tend to be very volatile and may therefore not be regarded in the same way as more traditional saving by the private sector. ${ }^{6}$ And, perhaps more importantly, year-to-year changes in capital gains do not really reflect deliberate saving-consumption considerations by individuals, making their inclusion in the saving aggregate less relevant to the analysis of how fiscal stance affects private saving. Second, data availability is an obstacle, and the valuation of assets will depend on an element of judgement, in particular for fixed assets in the public sector. Finally, at the aggregate level, capital gains may not increase future production and consumption (Auerbach, 1985). If the gains are due to changes in taste, and not to higher productivity on the existing capital stock, it may simply raise costs on other individuals or generations, in which case aggregate wealth and saving may not be affected. ${ }^{7}$

\subsubsection{Effects of inflation on the measurement of saving}

9. Inflation affects saving through the adjustment of nominal debt service payments. Higher inflation raises nominal interest payments and receipts while eroding the real value of debt and transferring wealth from creditors to debtors. ${ }^{8}$ Since a rise in nominal interest receipts is recorded in measured income in the National Accounts, but not the inflation tax on asset holdings (i.e. the erosion of the real value of government debt), the budget deficit will thus be overstated. Where private agents recognise the effect of inflation on asset holdings, their saving response would, in principle, be based on the perceived inflationadjusted budget balance.

\subsubsection{The aggregation of the household and corporate sectors}

10. The boundary between personal and corporate saving is somewhat arbitrary. ${ }^{9}$ Dividends and corporate share repurchases have, for example, different effects on the composition of private saving between households and corporations, although both involve shifting funds from the corporate to the household sector. Also, unincorporated companies are included in the household sector in the standard National Accounts, and incorporations of such companies will result in shifting saving from the household to the corporate sector. But aggregating the household and corporate sectors is not without problems. Corporate saving is typically much higher than household saving, and saving motives tend to differ

5. Reclassifying accrued and realised capital gains would imply that changes in saving equals changes in net wealth measured at market prices. However, as taxes on capital gains are usually paid when realised, this would overestimate private saving.

6. Similarly, realised capital gains by the public sector may not affect perceptions of future tax obligations in the same way as more structural changes in the government balance.

7. This is the case in a closed economy. In an open economy, capital gains -- also those stemming from changes in taste -- should count as national saving to the extent they raise the country's ability to purchase resources from other countries.

8. This effect is accentuated when real interest rates become negative, as has occurred temporarily in periods of accelerating inflation. In effect, inflation erodes the real value of government debt, which is equivalent to an (unrecorded) "tax" on bond-holders, and leads to an understatement of government saving in real terms.

9. See Gale and Sabelhaus (1999), for further discussion. 
between households and corporations. ${ }^{10}$ This may, in particular, be the case for public and foreigncontrolled enterprises, which play a non-negligible role in some countries. ${ }^{11}$

\subsubsection{The distinction between current and capital outlays}

11. The distinction between current and capital outlays in the National Accounts is not always relevant from an economic point of view. Spending on human capital (e.g. education and health care) or on research and development (R\&D), for example, is recorded as consumption, although rates of return may be comparable to those of investment in physical capital. ${ }^{12}$ Some public sector projects may have a negative present value and still be treated as investment. Public consumption and capital expenditure are often complementary (e.g. building hospitals and paying for health professionals), making the distinction less relevant from the viewpoint of taxpayers. Furthermore, purchases of durable goods (e.g. cars, furniture) are treated in the National Accounts as consumption if the purchaser is a household, and as investment, if the buyer is a firm. Reclassifying households' purchases of durable goods and spending on human capital and R\&D as investment would raise saving rates and affect saving patterns, as purchases of durable goods (and to some extent R\&D) in particular fluctuate significantly over the business cycle.

12. Another issue is whether to define saving gross or net of depreciation. Only net saving represents wealth accumulation, which may encourage private consumption. The calculation of depreciation is, however, associated with some uncertainty. And, although developments in gross and net saving may differ significantly over longer periods, this may not be true in the case of year-to-year fluctuations.

\subsubsection{Cyclical and other temporary factors affecting public saving}

13. Forward-looking, rational individuals should not react to changes in fiscal stance stemming from automatic stabilisers, as these reflect tax smoothing and not changes in the total tax take over the cycle. However, measuring public saving by the cyclically-adjusted budget balance is not without problems. Cyclically-adjusted indicators are generally not well known to the public and they are often revised substantially, especially at the end point. This makes such indicators less likely to affect private behaviour in the short run, and may imply that ex post calculations of changes in fiscal stance are less relevant as indicators of private sector expectations ex ante. Furthermore, large one-off items (e.g. revenues from sale of UMTS licences) -- which are taken into account by the Secretariat when calculating fiscal aggregates on a cyclically-adjusted basis -- may imply significant disguised shifts in fiscal aggregates from year to year, exaggerating changes in future tax obligations.

14. Forward-looking individuals should in principle react to news on current and future fiscal developments, as opposed to expected changes in the budget balance. In practice, implementation of political plans is often surrounded by significant uncertainty and may fail to be credible, but this is not always the case. Fiscal consolidation programs have sometimes enjoyed strong political commitment (as in many EU countries in the run-up to EMU), making private saving responses to announced policies more

10. In the United States, for example, corporate saving has accounted for around 80 per cent of private saving since 1995.

11. Although public enterprises are not consolidated in the general government sector, they affect public saving through above-the-line transfers (e.g. dividends). These transfers may be volatile in some countries, and introduce a bias in "public" saving, particularly when public enterprises are allowed to retain part of their profits and/or run deficits. In the United States, however, the general government fiscal balance includes the operating surpluses of public enterprises.

12. See Blondal et al. (2002). Expenditures on R\&D are usually treated as an intermediate input when financed by the private sector, and as consumption when funded by the public sector. 
likely. Multi-year budgeting may similarly anchor private expectations. The annual government balance may under such conditions fail to capture all relevant information. But constructing a more accurate indicator is difficult. ${ }^{13}$

\subsection{Trends in private and public saving}

15. OECD countries have experienced considerable swings in private and public saving over time (Figure 1). The OECD-wide private saving rate has trended down, and is now considerably lower than in the early 1970s, while public saving (measured by the cyclically-adjusted budget balance) has fluctuated, ending around its historical average. Across regions, changes in fiscal stance have often coincided with opposite co-movements in private saving, thus smoothing fluctuations in national saving. This is confirmed by an average correlation of close to -0.5 between changes in private saving and the cyclically-adjusted budget balance for the OECD area as a whole (Figure 2). However, such raw correlations should not be taken to indicate the extent to which changes in private saving offset shifts in public saving. A closer look at the 1990s reveals that the countries included in the sample (excluding Japan) experienced a significant improvement in the cyclically-adjusted government balance, with movements in private saving going in the opposite direction (France and Norway being exceptions). The magnitude of the co-movements differed considerably (Figure 3).

16. The above developments have coincided with a number of secular influences which could have affected private and public saving behaviour. In the first place, the process of capital market deregulation could have acted to facilitate consumption smoothing. Second, private and public saving have been affected by the movement toward price stability, which lowered not only nominal interest payments on public debt but also the inflation tax on asset holdings. If budget deficits are adjusted for the effect of inflation on debt and debt service payments (i.e. the inflation tax, measuring the erosion caused by inflation of the real value of government debt, is included as a government receipt), the improvement in budget balances in recent decades is, in some cases, significantly reduced (Figure 4).

\subsection{Episodes of sharp swings in fiscal stance}

17. Shifts in public saving can sometimes be associated with marked offsetting movements in private saving, with the result that fiscal contractions can be expansionary. This may occur via the effects of overall policy credibility on financial markets, in which the confidence and wealth effects associated with fiscal policy play a significant role. In particular, when fiscal policy becomes unsustainable, leading to accelerating inflation and rising interest rates, a fiscal correction can have a positive, stabilising effect. ${ }^{14}$ Since debt and wealth effects are distinctly non-neutral under these circumstances, these episodes fit neither the naïve Keynesian nor the Ricardian case. These movements appear not to occur in a linear fashion but to be associated with "trigger points", linked to large and unsustainable fiscal imbalances. ${ }^{15}$

13. One possibility could be to rely on information from consumer confidence indicators, and in particular the sub-index on households' expectations of future developments in government finances.

14. The European Commission (2003) provides a comprehensive study of the effects of past fiscal adjustments in the EU, as well as a survey of existing studies. Among the episodes of fiscal consolidation identified, around half of them have been expansionary.

15. The traditional channel for these non-Keynesian effects is private consumption (Giavazzi and Pagano, 1996, Giavazzi et al., 2000). But non-linear effects may also take place through private investment, as discussed by Alesina et al. (2002). 
Figure 1. Private and public saving: deviations from averages

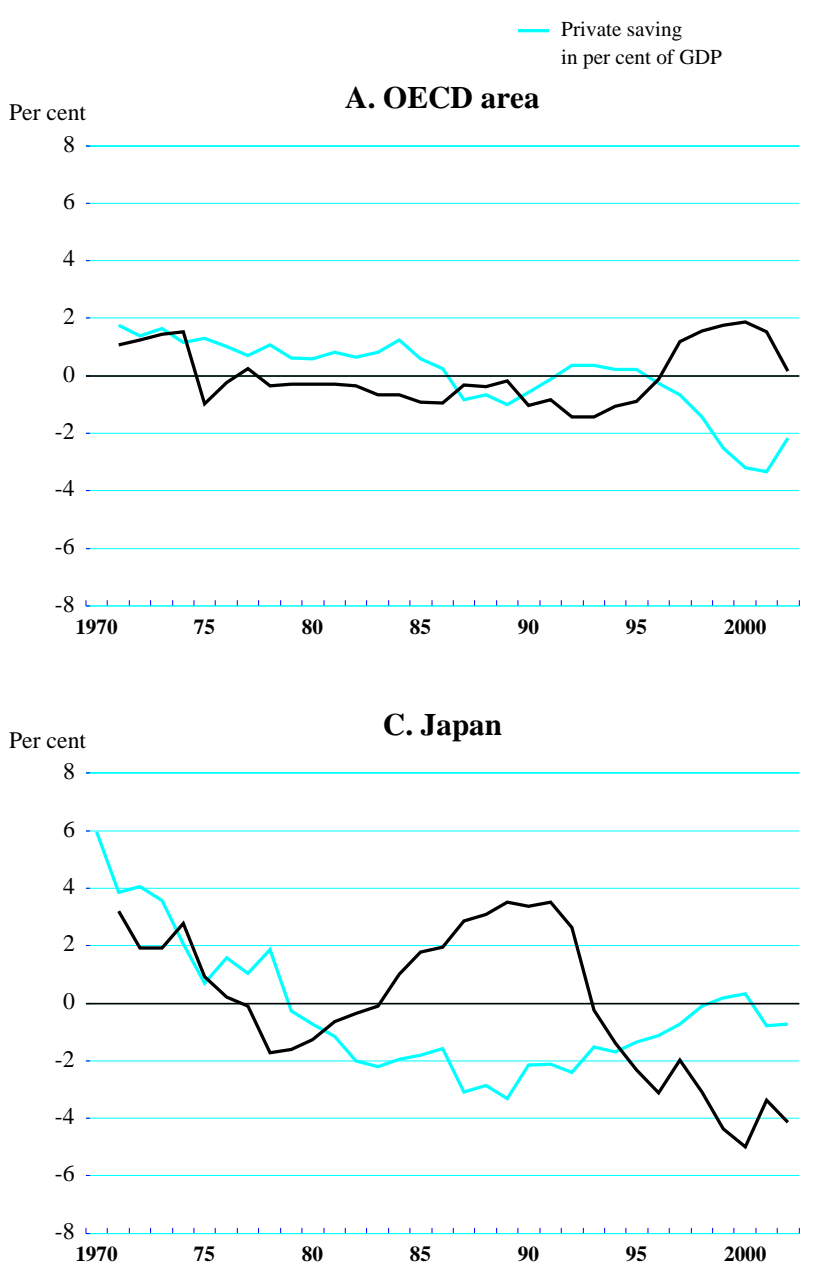
Cyclically-adjusted general government net lending
in per cent of potential GDP
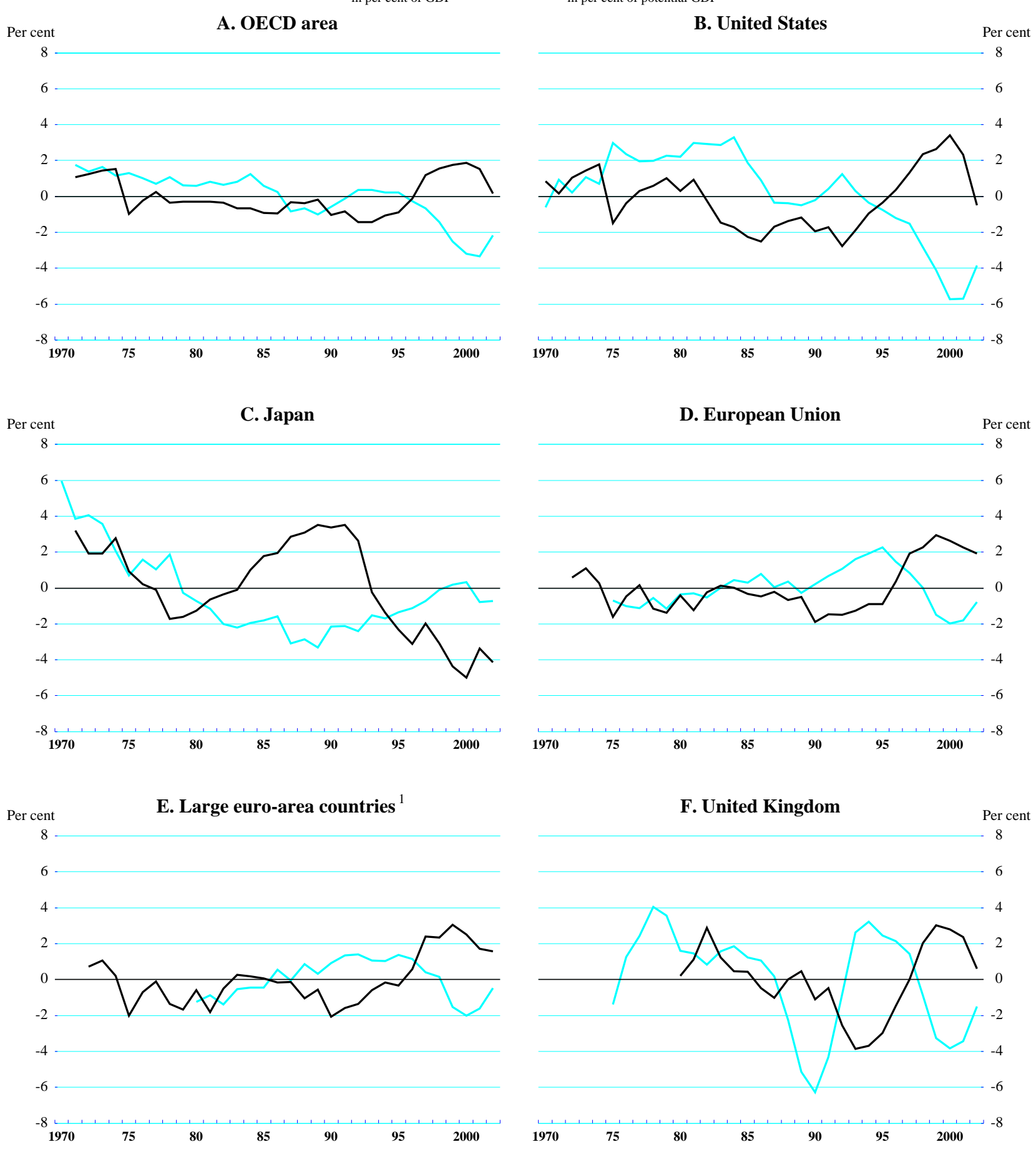

1. France, Germany and Italy.

Source: OECD Economic Outlook 74 Database. 
Figure 1. Private and public saving: deviations from averages (continued)

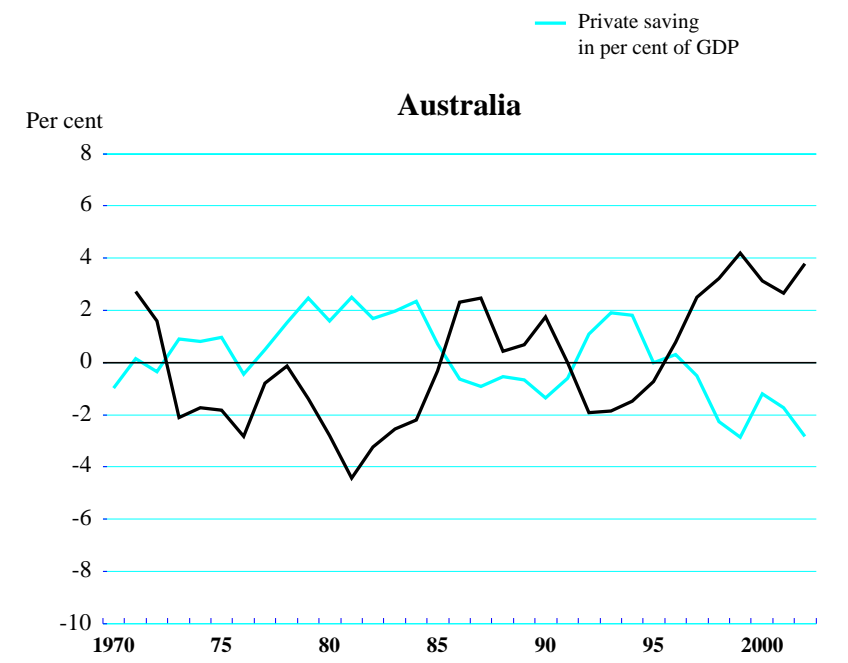

$$
\begin{aligned}
& \text { - Cyclically-adjusted general government net lending } \\
& \text { in per cent of potential GDP }
\end{aligned}
$$
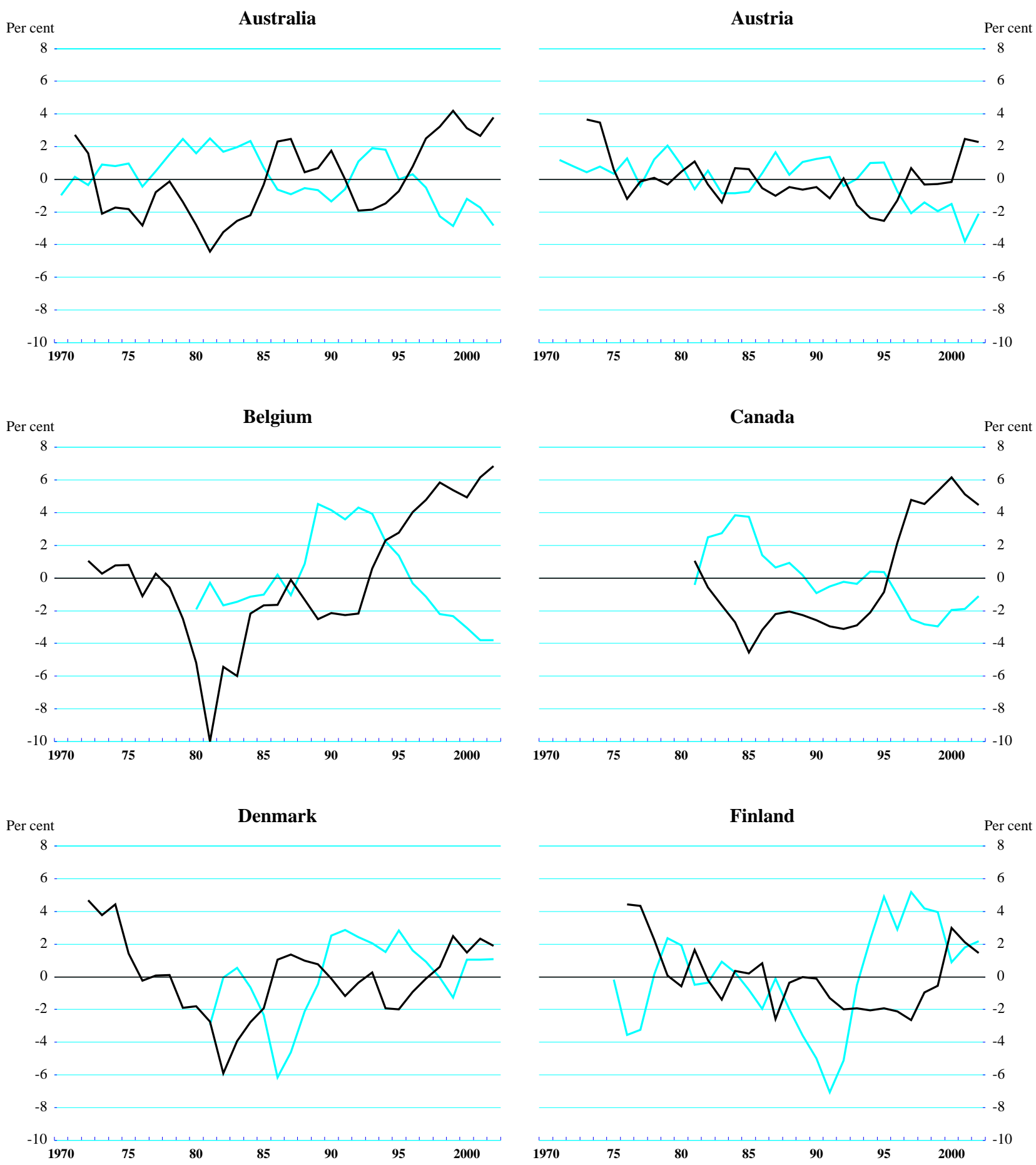

Source: OECD Economic Outlook 74 Database. 
Figure 1. Private and public saving: deviations from averages (continued)

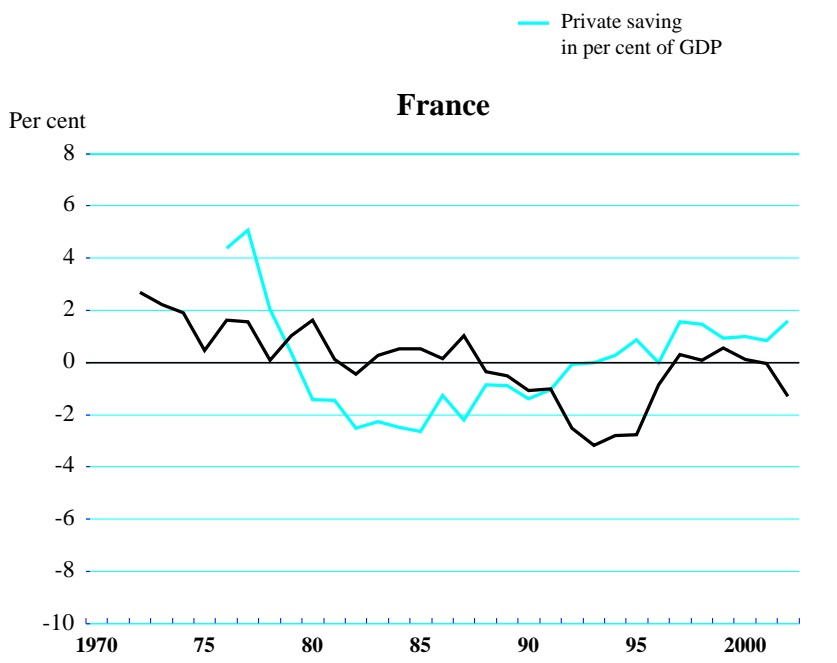

$$
\begin{aligned}
& \text { - Cyclically-adjusted general government net lending } \\
& \text { in per cent of potential GDP }
\end{aligned}
$$
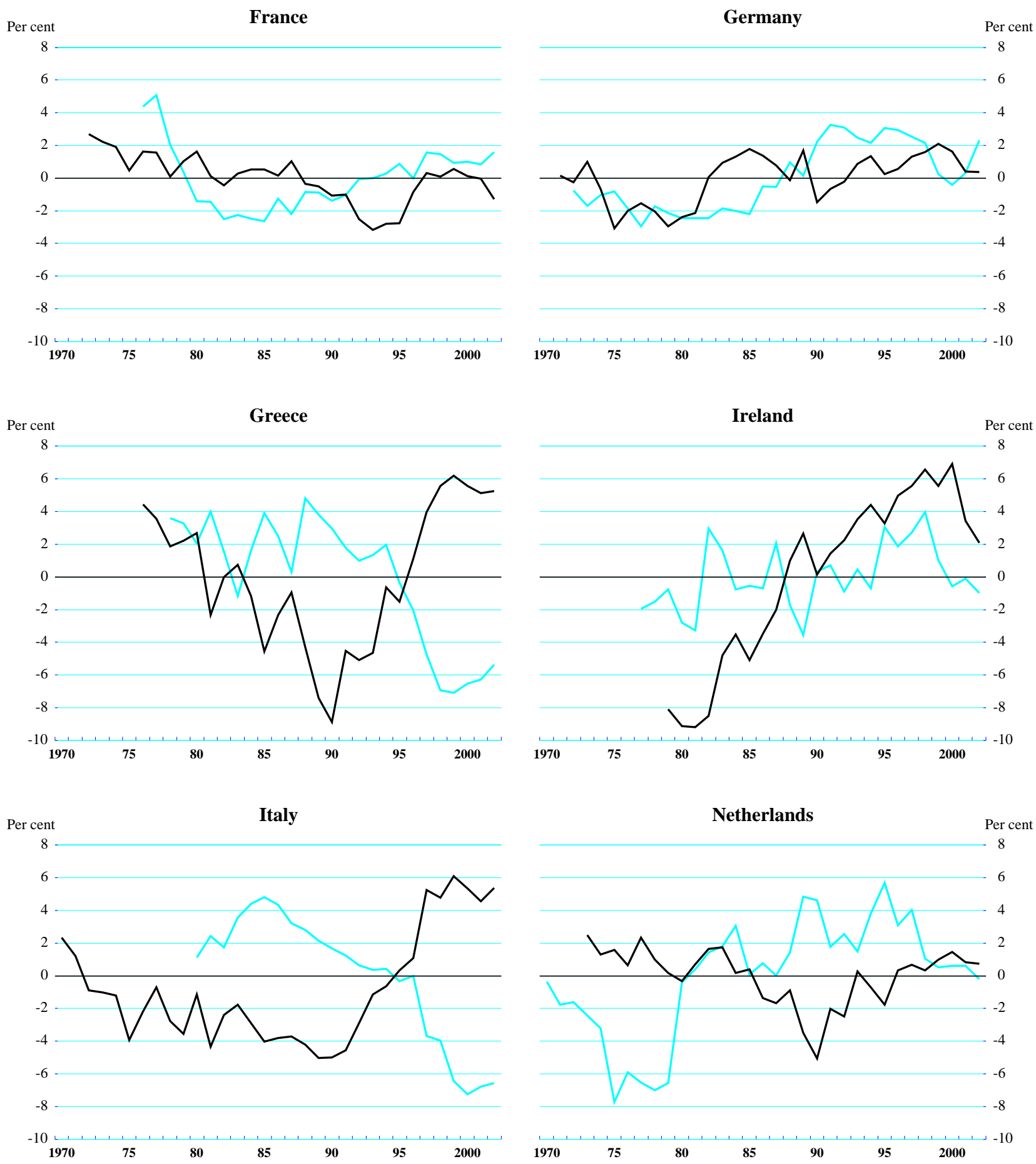

Source: OECD Economic Outlook 74 Database. 
Figure 1. Private and public saving: deviations from averages (continued)

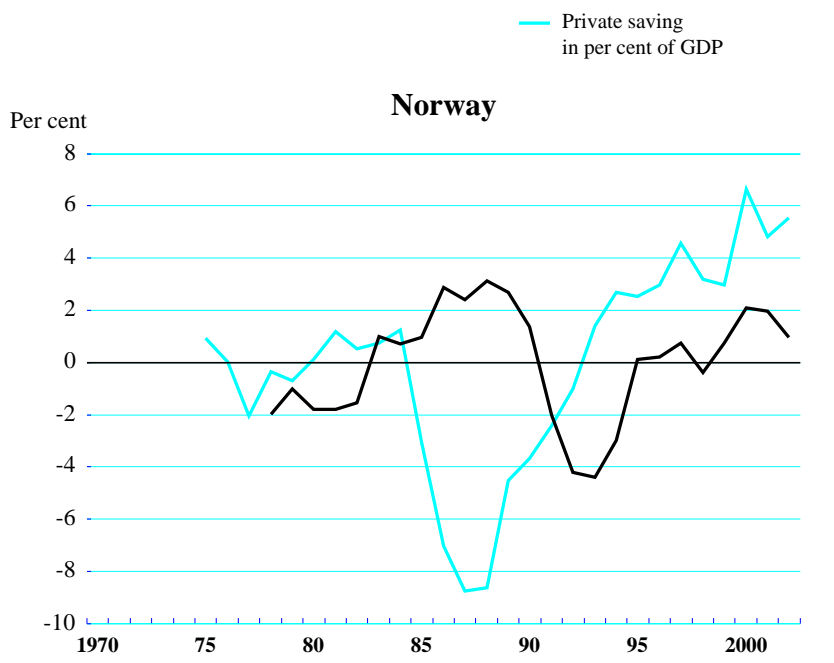

$$
\begin{aligned}
& \text { Cyclically-adjusted general government net lending } \\
& \text { in per cent of potential GDP }
\end{aligned}
$$
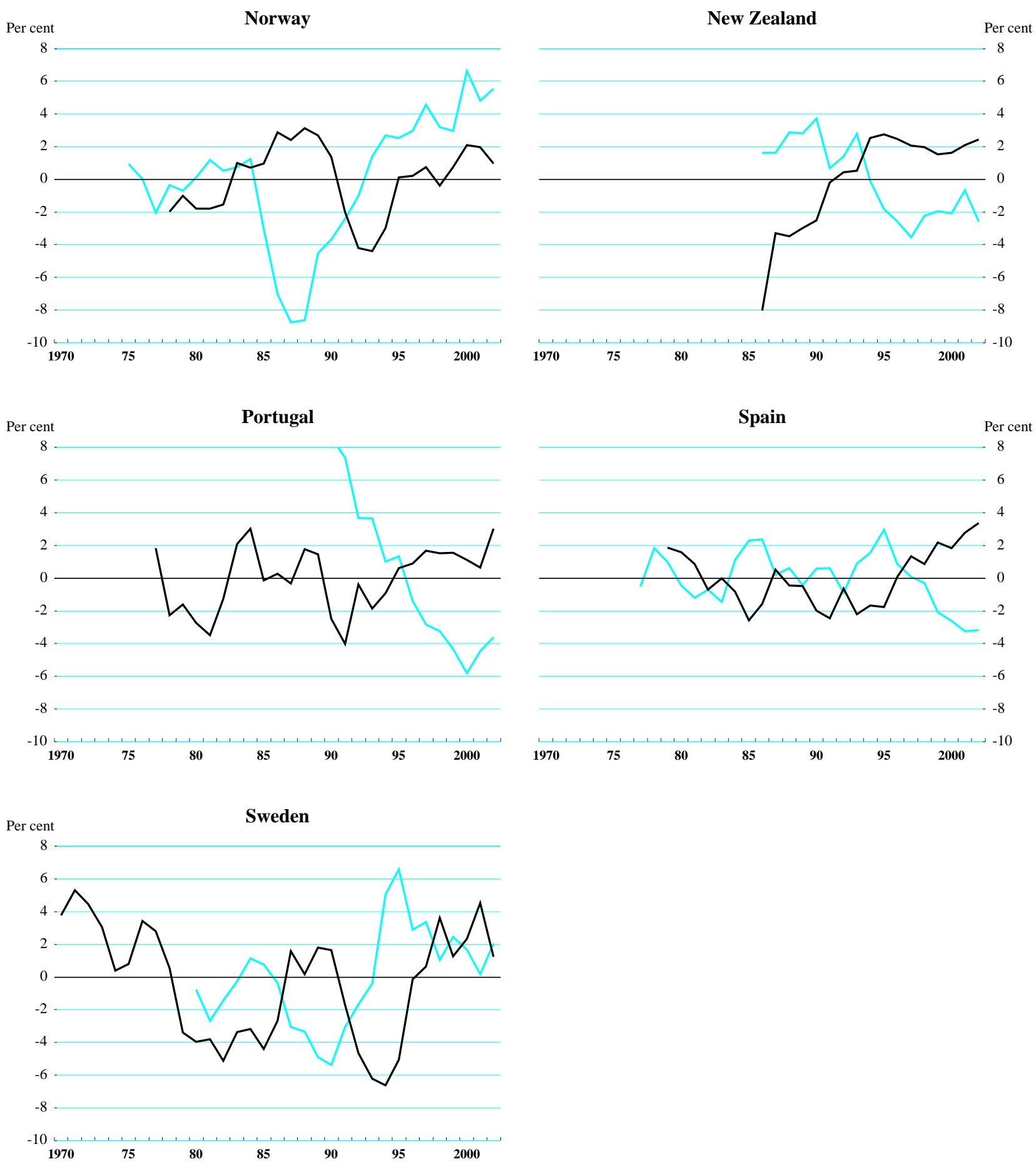

Source: OECD Economic Outlook 74 Database. 
Figure 2. Private and public saving: raw correlations ${ }^{1}$

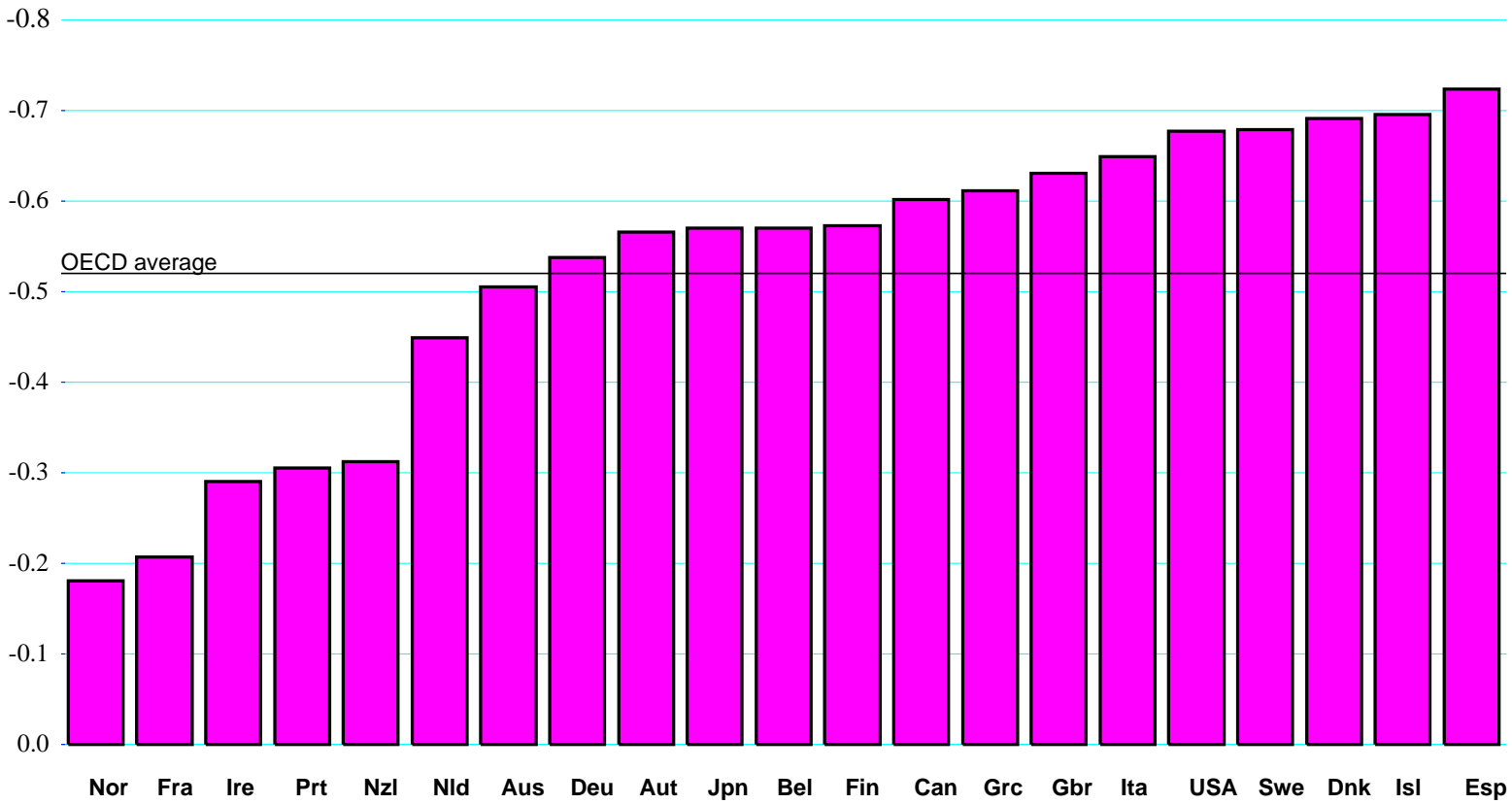

1. Correlation between changes in private saving and in the cyclically-adjusted budget balance between 1970-2002 (data range varies according to data availability).

Source: OECD Economic Outlook 74 database. 
Figure 3. Change in private and public saving Per cent of GDP

Drivate saving $\quad$ Cyclically-adjusted balance

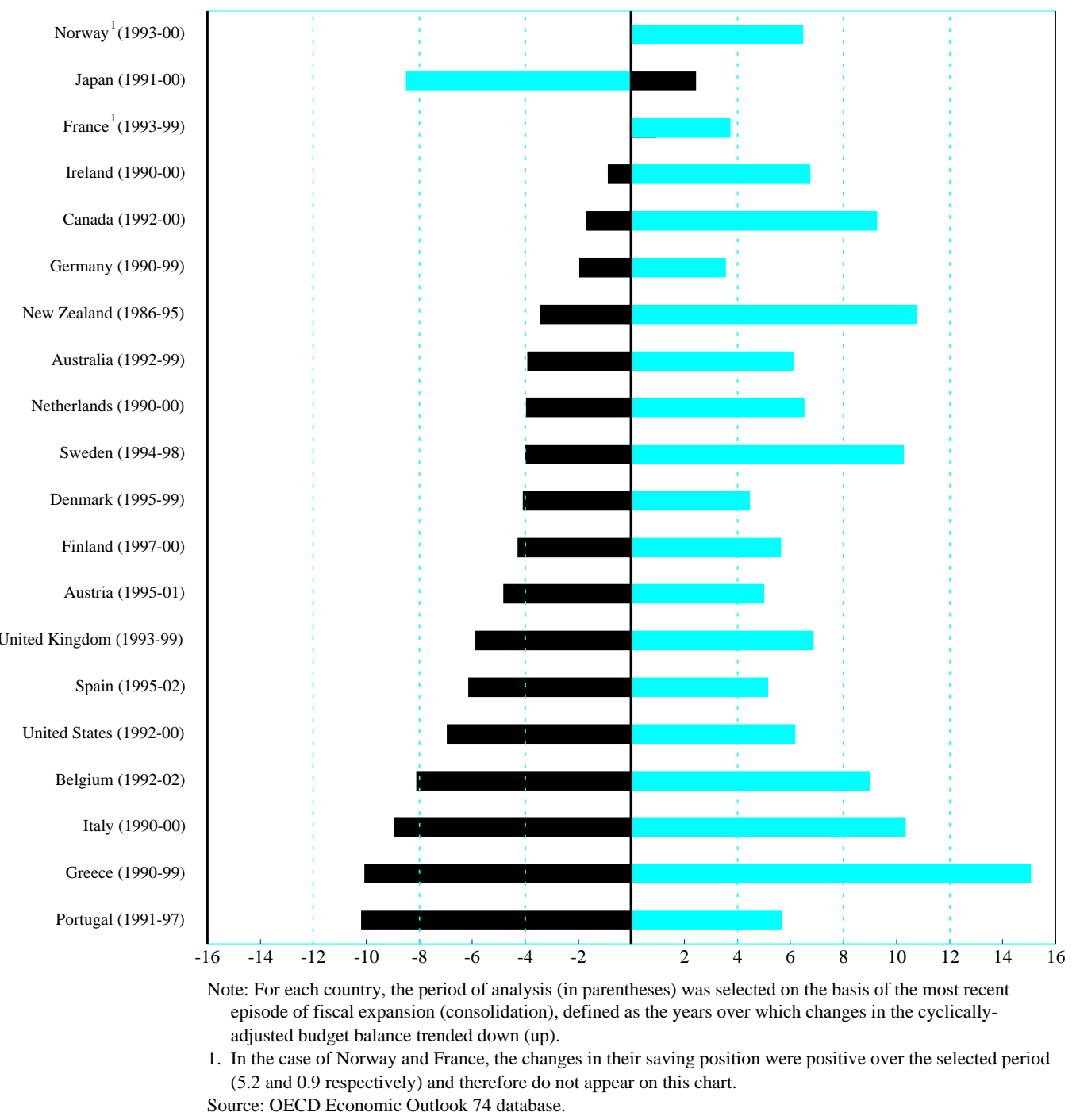


Figure 4. Public saving: inflation adjustment Per cent of potential GDP

— Cyclically-adjusted general government net lending

Per cen

5

3

1

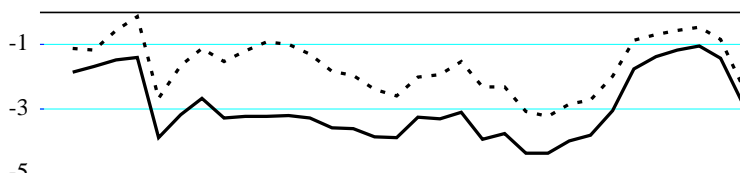

$-5$

$-7$

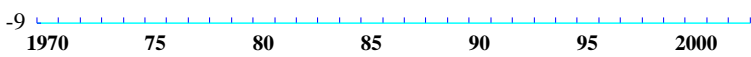

Per cent

C. Japan

5

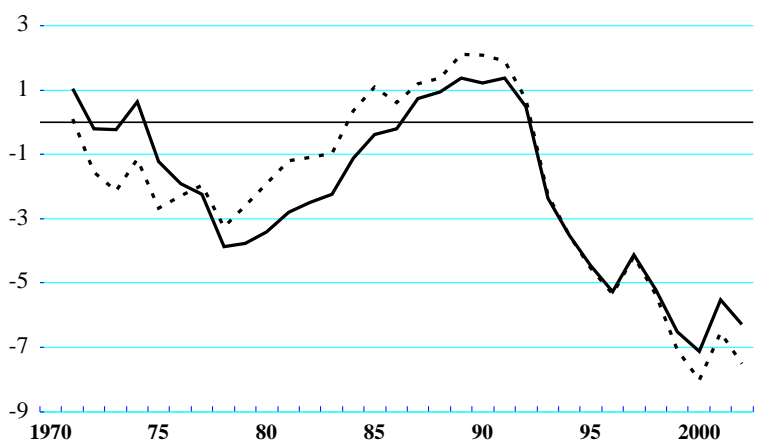

Per cent

E. Large euro-area countries ${ }^{2}$

5

3

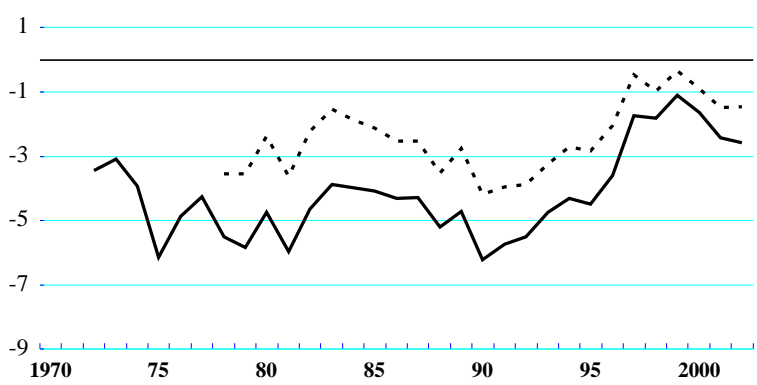

- . Cyclically-adjusted general government net lending corrected for inflation ${ }^{1}$

B. United States

Per cent

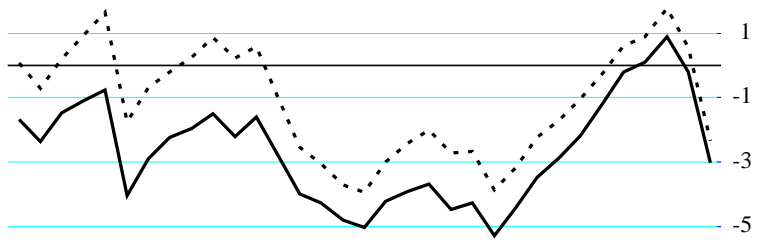

$-7$

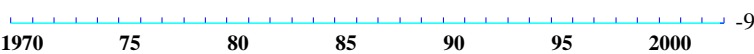

D. European Union

Per cent

3

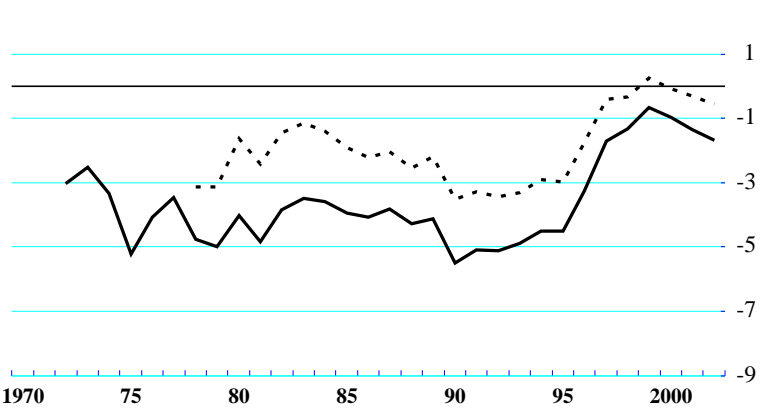

F. United Kingdom

Per cent
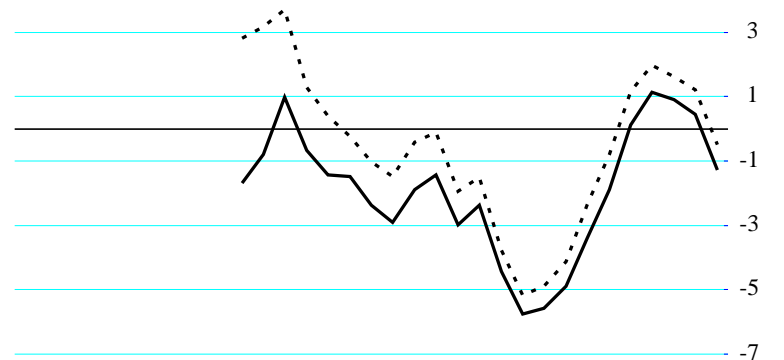

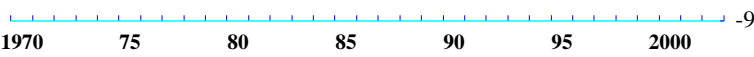

1. The adjusted fiscal balance-to-GDP ratio is equal to the raw ratio plus a 3-year moving average of inflation (based on GDP deflator) times net public debt in the previous year.

2. France, Germany and Italy.

Source: OECD Economic Outlook 74 Database. 
18. Two cases relate to Denmark and Ireland in the 1980s (see Appendix 1, for more information). The Danish fiscal stabilisation of 1983-86 was achieved by retrenching real government consumption, cutting back public investment and raising taxes. The reduction in the deficit was accompanied by a boom in private consumption and investment, backed by positive wealth effects. In Ireland, the post-1987 stabilisation programme -- accomplished by slashing government consumption and investment -- was the trigger for higher growth. Conversely, an episode that has often been referred to as a contractionary fiscal expansion relates to the rapid increase in the budget deficit in Sweden in the early 1990s. Occurring on the back of a bail-out of financial institutions and tax cuts, the budget deficit shift was offset by rising private saving, due to the negative wealth effects associated with the concomitant fall in housing prices. A common characteristic of these episodes is the presence of strong exogenous wealth effects, which makes it difficult to isolate fiscally-induced effects per se, or to identify pure Ricardian responses.

19. There is also evidence of strongly offsetting movements in private and public saving in less extreme cases, when fiscal policies are not deemed unsustainable, but again separating pure fiscal responses from other wealth factors is very difficult. The United States experience during the 1990s provides an example of a fiscal consolidation -- based on public spending restraint and revenue windfalls on realised capital gains -- associated with a significant decline in private saving. However, while fiscal consolidation provided some of the room for productive investment increase associated with the asset-price boom, other ("new economy") factors were probably more important. Similarly, the fiscal expansion in Japan over the same period, which was predominantly expenditure-based, saw the private saving ratio rise substantially. But again, the substantial negative wealth effects which occurred were more closely related to exogenous factors, in the form of the decline in equity and land prices, than to fiscal easing.

20. Two inferences may be drawn from these episodes. On the one hand, exogenous wealth effects may obscure the presence of Ricardian behaviour. On the other hand, budget deficit shifts may themselves elicit wealth responses, and associated private saving developments, which are difficult to distinguish from Ricardian behaviour. Such wealth responses seem to depend on the nature and composition of changes in fiscal stance and the policy actions with which they are packaged. In particular, from case-study evidence, consolidation based on spending cuts may generate greater private saving offsets than when based on tax increases because the resulting wealth and crowding-in effects are stronger ${ }^{16}$ Correspondingly, expansions (whether tax or spending induced) may have negative wealth and confidence effects, depending on the initial fiscal and economic conditions. The next section attempts to test for these effects more formally, while identifying Ricardian responses per se.

\section{The private saving offset: some empirical evidence}

\subsection{Estimation strategy and data}

21. The relationship between private and public saving can be estimated in an error-correction set-up as follows:

$$
S_{i t}^{p r i v}=\alpha_{0}+\alpha_{1} S_{i t}^{p u b}+\alpha_{2} X_{i t}+e_{i t}, \text { and }
$$

16. The composition of fiscal adjustment affects its likelihood of success. Zaghini (1999) suggests that shifting the composition of retrenchment toward expenditure cuts increases the probability of success. Alesina and Perotti (1995), McDermott and Wescott (1996), Alesina and Ardagna (1998), Alesina et al. (1998) report similar findings. Giavazzi et al. (2000) suggest that offsetting saving responses are stronger during large fiscal contractions, but particularly when based on tax measures. Wealth effects are strengthened if interest rates come down as a result of the fiscal consolidation, to the extent that corrective measures, if credible, contribute to reducing risk premia (Blanchard, 1990, and Zaghini, 1999). 


$$
\Delta S_{i t}^{p r i v}=\beta_{0}+\beta_{1} \Delta S_{i, t-1}^{p r i v}+\beta_{2} e_{i, t-1}+\beta_{3} \Delta S_{i t}^{p u b}+\beta_{4} \Delta X_{i t}+v_{i t} \text {, with } \beta_{2}<0,
$$

where $S_{i t}^{p r i v}$ and $S_{i t}^{p u b}$ denote, respectively, the private and the public saving ratios in country $i$ at time $t$, $X_{i t}$ is a vector of control variables, $e$ and $v$ are disturbance terms, and $\Delta$ is the first-difference operator.

22. Equations (1)-(2) can be estimated jointly by solving equation (1) for $e_{i, t-1}$ and substituting for it into equation (2), which allows for the including in the estimating equation of the RHS variables in firstdifferences and in lagged levels, such that:

$$
\Delta S_{i t}^{p r i v}=\left(\beta_{0}-\beta_{2} \alpha_{0}\right)+\beta_{1} \Delta S_{i, t-1}^{p r i v}+\beta_{2} S_{i, t-1}^{p r i v}+\beta_{3} \Delta S_{i t}^{p u b}-\beta_{2} \alpha_{1} S_{i, t-1}^{p u b}+\beta_{4} \Delta X_{i t}-\beta_{2} \alpha_{2} X_{i, t-1}+v_{i t}
$$

23. Equation (3) allows for the direct estimation of the private saving offset and innovates with respect to previous empirical literature by using an error-correction specification for the reduced-form saving equation. ${ }^{17}$ Empirical studies have also focused on the association between public saving and private consumption, such as Giavazzi and Pagano (1996), on the one hand, and national saving, as in Giavazzi et al. (2000), on the other. Previous empirical studies focusing on private, rather than national, saving as a left hand-side variable in a reduced-form saving equation include Loayza et al. (2000), and de Serres and Pelgrin (2003). Exclusive focus on household, rather than private or national, saving, such as Callen and Thimann (1997), is relatively uncommon in empirical literature. In any case, a partial equilibrium set-up is often used, in which the saving equation is estimated as follows:

$$
S_{i t}^{p r i v}=\gamma_{0}+\gamma_{1} S_{i, t-1}^{p r i v}+\gamma_{2} S_{i t}^{p u b}+\gamma_{3} X_{i t}+u_{i t}
$$

24. The coefficient of interest in Equation (4) is $\gamma_{2}$. The hypothesis of a strict private saving offset is accepted so long as $\gamma_{2}=-1$, controlling for other private saving determinants. A partial offset (i.e., the estimated coefficient $\gamma_{2}$ is negative but statistically less than 1) suggests that fiscal impulses remain expansionary, with movements in public saving being only partially mitigated by co-movements in private saving in the opposite direction.

25. The set of control variables, discussed in greater detail in Box 2, is standard in empirical literature, and includes the old-age dependency ratio, the real interest rate, consumer price inflation, changes in the terms of trade, the ratio of broad money (M2) to GDP, and the growth rate of per capita GDP.

\section{Box 2. Private saving equations: conventional control variables}

The set of control variables includes conventional determinants of private saving, such as the old-age dependency ratio, the real interest rate, inflation, changes in the terms of trade, proxies for financial deepening (e.g. credit-to-GDP ratio, M2-to GDP ratio, interest spread, etc.), and the per capita GDP growth rate. These controls

17. The advantage of using a reduced-form saving equation in the empirical analysis is that it allows for the estimation of the private saving offset with a large set of control variables. Structural models, on the other hand, have the advantage of testing more directly the different premises on which different theoretical models rest, based on first-order conditions, but do not allow for the inclusion of a large number of controls. The advantages and shortcomings of different estimation strategies are discussed in greater detail in, for example, Haque et al. (1999), Elmendorf and Mankiw (1999), and Ricciuti (2003). 
have been used extensively in the empirical literature based on reduced-form equations, including Haque et al. (1999); Masson et al. (1998); Loayza et al. (2000), and de Serres and Pelgrin (2003).

There is considerable ambiguity over the expected signs of some of the control variables. The old-age dependency ratio is expected in principle to be negatively correlated with private saving through life-cycle effects. But when aggregate, rather than household-level, saving ratios are used, the correlation may be affected by interactions between generations, such as bequests to younger cohorts, which may reduce aggregate saving even though older cohorts may not dissave. Terms of trade shocks are expected to be positively correlated with private saving to the extent that they are perceived as temporary, through the Harberger-Metzler effect. Permanent shocks should not affect private saving. The effects of inflation and real interest rate are ambiguous, and generally of poor predictive power, depending largely on the extent of credit constraints and on the relative magnitude of income and substitution effects. Also, higher, and/or accelerating, inflation erodes the real value of debt and raises private saving, as discussed above, but also discourages holdings of assets that are not inflation-indexed. The impact of GDP growth on private saving is also ambiguous, as well as that of capital deepening.

Other control variables can also be considered, based on recent empirical literature. In principle, household wealth is expected to affect consumption/saving decisions based on permanent income considerations, but data are not readily available for most countries. Also, the effect of financial liberalisation on private saving is ambiguous, because improved access to credit may boost consumption but the removal of bank portfolio allocation constraints, which often accompanies financial liberalisation, may result in higher real interest rates, which encourages saving. ${ }^{2}$ Again, adequate proxies are difficult to find, as well as identifying the timing of these effects. The extent and coverage of government-run social security, to the extent that it crowds out privately-run alternatives, which are more likely to encourage private shrift, may also be considered, although data limitations are often difficult to overcome. Moreover, the external current account balance can be taken as an additional determinant, as has become customary in large cross-sectional studies including developing countries subject to external borrowing constraints, to assess the extent to which foreign saving crowds out domestic private saving. Income distribution can also be considered as an additional explanatory variable, on the grounds that it allows for greater consumer heterogeneity. To the extent that the distributions of income and wealth differ significantly, poorer individuals are less able to smooth consumption over their lifetime, whereas wealthier individuals smooth consumption not only throughout their own life but also across generations via bequests. ${ }^{3}$ In the same vein, precautionary motives are important determinants of saving but quantifiable proxies are often difficult to come by. ${ }^{4}$ Productivity could also be considered, to the extent that it affects long-term income growth and hence current consumption/investment decisions, with a drop in productivity being expected to lead to higher saving.

1. Using a panel of 19 OECD countries, Perotti (1999) shows that, in more credit-constrained economies, based on the ratio of mortgage loan to property value, the transmission mechanism of government spending shocks to private consumption is stronger than in economies with more severe credit constraints. Masson et al. (1998) also report correlations between private saving and real interest rates that are not robust.

2. Pozzi et al. (2003) do not find a strong correlation between financial liberalisation and private consumption in a panel of OECD countries.

3. It can also be argued that the distribution of income and wealth is affected by fiscal policy to the extent that higher debt is associated to higher interest payments, which accrue to higher-income individuals, who are net savers, widening the gap between low-income spenders and high-income savers. For further discussion, see Mankiw (2000).

4. See Carroll (1997), for further discussion on buffer-stock saving behaviour.

26. Several estimators have been used to estimate reduced-form equations such as Equations (3) and (4), including the pooled mean group (PMG) estimator, which allows for cross-country heterogeneity in the coefficients, and a variety of GMM estimators, which deal with persistence in saving dynamics and joint endogeneity among the regressors. Although appealing, the possibility of slope heterogeneity may be exaggerated in the case of public saving, the main parameter of interest in this analysis. Evidence reported using the pooled mean group estimator does not suggest that the response of private saving to public saving differs significantly across countries (Haque et al., 1999; de Serres and Pelgrin, 2003). Given the expected serial correlation in the residuals, measurement errors in the saving ratios, as discussed above, and endogeneity of fiscal policy, a GMM estimator is preferred. In particular, the Arellano-Bond (1991) difference-GMM estimator estimates the regression in first differences, including the lagged dependent 
variable among the right hand-side variables, and uses the levels of the endogenous variables as instruments, with conventional identification restrictions being used to test for orthogonality between the instruments and the error terms.

27. Country selection has been guided by data availability. The dataset covers at most 21 OECD countries spanning the period 1970-2002, including all the current members of the European Union (except Luxembourg), Australia, Canada, Iceland, Japan, New Zealand, Norway, and United States. The main source of data is the OECD Economic Outlook database. Descriptive statistics of the saving and fiscal aggregates, as well as the control variables, are reported in Table A2.1.

\section{2. $\quad$ Baseline results}

28. Being based on pooled cross-country and time-series data, the aim of the empirical analysis is to highlight OECD-wide trends, rather than individual country experiences. Equation (3) is estimated using the difference-GMM estimator to take account of inertia in saving behaviour and the joint endogeneity of the explanatory variables. ${ }^{18}$ Estimation of the baseline regressions yields the parsimonious models reported in Table 1 below. ${ }^{19}$ The preferred specification includes proxies for wealth effects (equity market and housing price indices), in addition to the conventional controls. ${ }^{20}$ When the conventional controls are included, the Sargan test of overidentifying restrictions does not reject the orthogonality of the instruments and the error terms, thus underscoring the appropriateness of the model specifications. The tests of firstand second-order serial correlation of the first-differenced error terms also confirm the adequacy of the lags of the explanatory variables used as instruments in the models reported.

29. The private saving offset is estimated at about one-half in the short term. The corresponding long term offsets is estimated at about three-quarters. ${ }^{21}$ The magnitudes of these estimated offsets suggest that, in response to a fiscal tightening of approximately 5 per cent of GDP -- comparable to that of the OECD area as a whole in the previous upturn, between 1993-2000 -- private saving is expected to fall by about $2^{1 / 2}$ per cent of GDP over the period. The effect on national saving of a fiscal easing of this magnitude, all else unchanged, is therefore of a rise of about $2 \frac{1}{2}$ per cent of GDP. The saving offset would be greater over the longer term, with changes in fiscal stance being almost totally offset by changes in private saving, leaving national saving largely unaffected.

30. The control variables affect the private saving dynamics as follows: $i$ ) fluctuations in the terms of trade are positively associated with private saving in the short term; $i$ ) broad money affects private saving negatively in the short term; and the old-age dependency ratio and the equity market index affect private saving negatively in the long term. The proxies for wealth effects appear to have a statistically significant

18. First-step estimates are reported throughout.

19. A variety of unit root tests was carried out for the individual times series and the panel as a whole, suggesting that the variables of interest are mon-stationary. The cointegration test proposed by Pedroni (1999) and Kao (1999) was also carried out, suggesting that there is a stable long-term relationship between private and public saving. This error-correction specification is also used by Cotis, Coppel and de Mello (2004).

20. An alternative to the use of proxies for wealth effects is to use direct measures of net household financial wealth, but data are only available for a small sub-sample of countries, as depicted in Figure 5 (Canada, France, Germany, Japan, Italy, United Kingdom, and United States).

21. The long-term private saving offset can be calculated by dividing the estimated coefficient on $S_{i, t-1}^{p u b}$ by minus the estimated coefficient on $S_{i, t-1}^{\text {priv }}$. 
effect on private saving, with an increase in housing and equity prices acting to reduce private saving in both the short and long terms.

31. As noted, the extent to which movements in private saving offset those in the cyclically-adjusted budget balance is also affected by fluctuations in household wealth, which may themselves be correlated with budget action, rather than strict tax discounting. The decline in private saving rates in the late 1990s often coincided with increased household net worth associated with stock-market and housing price booms, as well as declining budget deficits (Figure 5). The decline in equity wealth since 2000 has taken place concomitantly with an expansionary fiscal stance and an increase in private saving rates during 2001-03. ${ }^{22}$ Whether coincident with budgetary changes, or in part related to them, it is difficult to disentangle the effects of wealth-induced shifts in saving from those deriving from public sector indebtedness per se, and exclusion of these proxies would overstate Ricardian effects.

\subsection{Robustness analysis}

32. For comparison purposes, results of the estimation of the partial-equilibrium model defined in Equation (4) are reported in Table 2. The short-run private saving offset is estimated at about 30 per cent in the OECD area, within an intermediate range of estimates reported in recent empirical literature, against one-half in the error-correction model. ${ }^{23}$ Because of considerable persistence in private saving, the estimated private saving offset is stronger in the long run than in the short term. ${ }^{24}$ This may also be attributed, at least in part, to the fact that the partial-equilibrium equations take account of inertia in private saving but do not allow for more complex dynamics in the adjustment towards the long-term equilibrium, which can be better treated in an error-correction set-up. The effect of the control variables on private saving is as follows: fluctuations in terms of trade are positively associated with private saving, whereas the old-age dependency ratio, and the real interest rate are negatively signed, as expected, and fairly robust across specifications. ${ }^{25}$ Broad money does not seem to affect private saving in a statistically significant manner. ${ }^{26}$ The proxies for wealth effects due to equity and housing market cycles are robust across specifications, being negatively correlated with private saving.

22. See IMF (2003), for further discussion and empirical evidence for the United States. For further discussion on the effect of movements in housing prices on private consumption, see Boone et al. (2001).

23. The estimated private saving offset is greater in magnitude than that reported by Loayza et al. (2000) for OECD countries (about 0.1 ), using a comparable GMM estimator, but lower than those reported by Haque et al. (1999) and de Serres and Pelgrin (2003) using error-correction mean group estimators (about 0.9 and 0.7, respectively); by Masson et al. (1998), using a static fixed-effects estimator (about 0.8), and by Edwards (1996), for both industrial and developing countries using an instrumental variables estimator (about 0.6).

24. Based on equation (4), the long-term private saving offset is defined as $\gamma_{2} /\left(1-\gamma_{1}\right)$, with $\gamma_{2}$ denoting the short-term response.

25. The results are robust to the use of long-term, rather than short-term, interest rates.

26. Loayza et al. (2000) report reduced-form private saving equations in which the ratio of broad money (M2) to GDP is a weak predictor of private saving, as well as the real interest rate and the old-age dependency ratio. However, their findings suggest that inflation is a powerful determinant of private saving in the OECD area. 
Table 1. Sensitivity of private saving to fiscal stance: error-correction models

Dep. Var.: Private saving (in per cent of GDP, National Accounts definition): ${ }^{a}$

Private saving

Lagged first difference

\begin{tabular}{lll} 
Baseline & 1 & 2 \\
\hline
\end{tabular}

Lagged level

Public saving (net lending ${ }^{b}$ )

First difference

Lagged level

\begin{tabular}{|c|c|c|}
\hline $0.11 * *$ & $0.11 * *$ & $0.12 * *$ \\
\hline (0.039) & (0.047) & $(0.048)$ \\
\hline $\begin{array}{l}-0.21 * * * \\
(0.026)\end{array}$ & $\begin{array}{l}-0.27 \text { *** } \\
(0.034)\end{array}$ & $\begin{array}{l}-0.27 \text { *** } \\
(0.034)\end{array}$ \\
\hline$-0.58 * * *$ & $-0.51 * * *$ & $-0.54 * * *$ \\
\hline (0.044) & (0.048) & $(0.050)$ \\
\hline$-0.17 * * *$ & $-0.19 * * *$ & $-0.21 * * *$ \\
\hline (0.028) & $(0.034)$ & $(0.043)$ \\
\hline & & $\begin{array}{r}0.07 * \\
(0.040)\end{array}$ \\
\hline
\end{tabular}

Controls

Broad money (first difference)

$\begin{array}{cc}-0.1 \text { *** } & -0.09 \text { *** } \\ (0.271) & (0.029) \\ 0.04 * * * & 0.05 * * * \\ (0.012) & (0.013) \\ -0.28 * * * & -0.27 * * * \\ (0.057) & (0.057) \\ 0.32 & 0.04 \\ (0.027) & (0.028) \\ -0.02 * * * & -0.02 \\ (0.008) & (0.008) \\ -0.02 * * * & -0.02 * * * \\ (0.004) & (0.004) \\ -0.01 * * * & -0.005 * * * \\ (0.001) & (0.001)\end{array}$

Memorandum items:

Implied long-term offset

$-0.81$

$-0.70$

$-0.78$

High debt

$\ldots$

...

Debt $>70.8$

No. of observations

No. of cross-sectional units

$$
448
$$

275

255

21

16

16

0.45

0.99

0.99

0.00

0.00

0.00

First-order autocorrelation ( $p$-value)

0.40

0.40

0.28

a) All models are estimated using the Arellano-Bond difference-GMM estimator and include a common intercept (not reported). Standard errors are reported in parentheses. Statistical significance at the 1,5 , and 10 per cent levels is denoted by respectively $(* * *),(* *)$, and $(*)$.

b) Net lending is cyclically adjusted.

Source: OECD Economic Outlook database. 
Figure 5. Public debt and net financial wealth in selected OECD countries

- Net financial wealth (left axis)

Canada

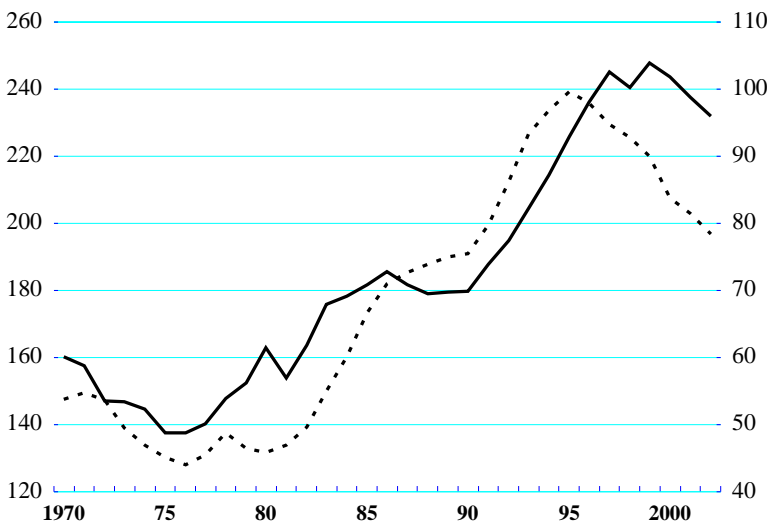

Italy

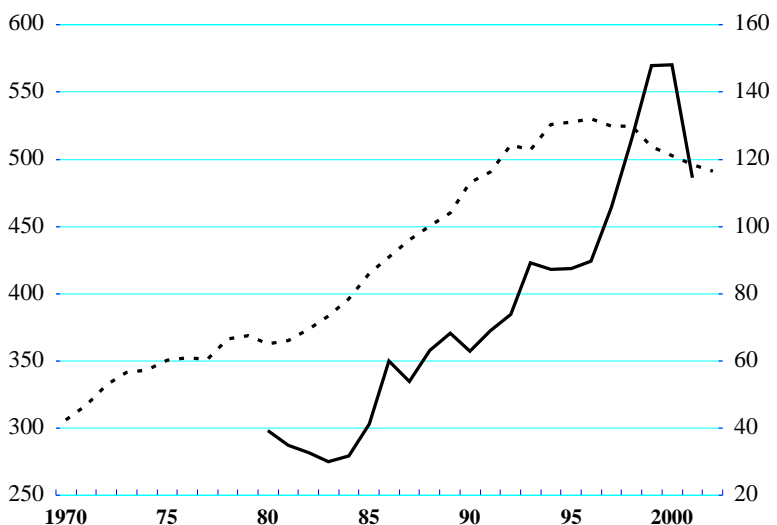

United Kingdom

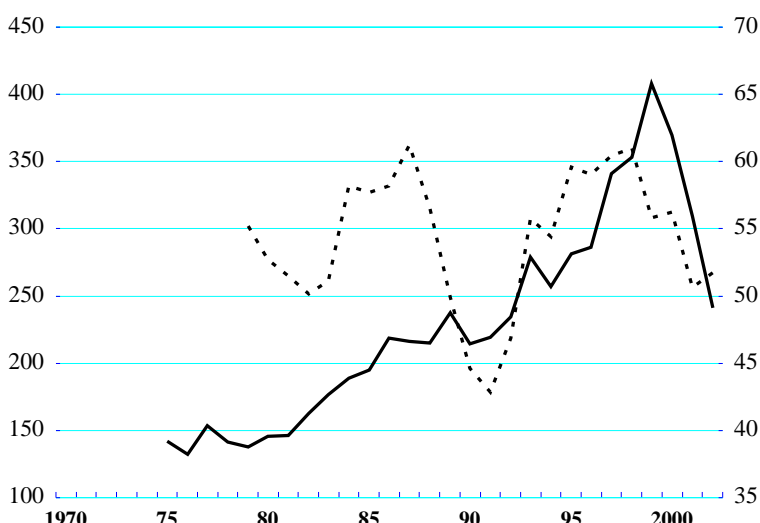

Source: OECD Economic Outlook 74 Database.
. Public debt (right axis)

in per cent of potential GDP

\section{France}

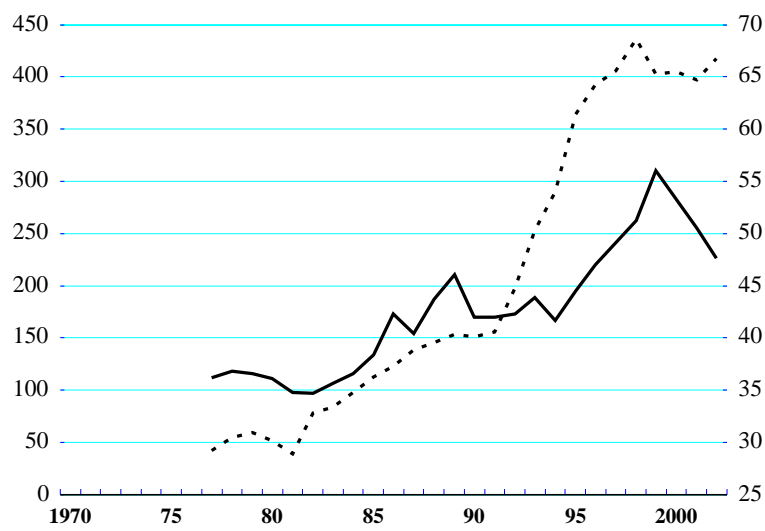

Japan

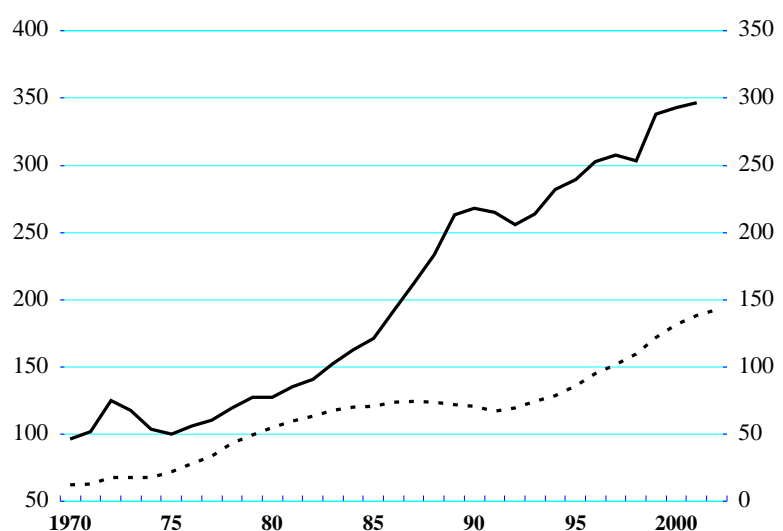

United States

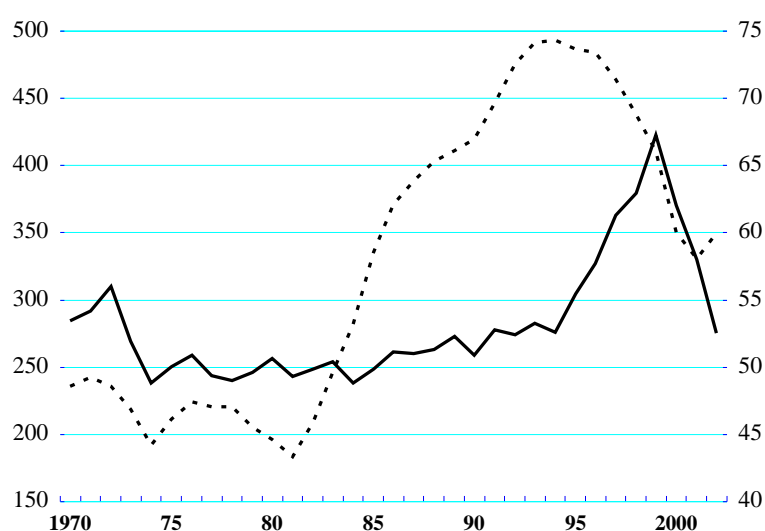


Table 2. Sensitivity of private saving to fiscal stance: partial equilibrium models

Dep. Var.: Private saving (in per cent of GDP, National Accounts definition): ${ }^{a}$

Lagged private saving

Public saving (net lending ${ }^{b}$ )

Net lending

Net lending * high debt

Controls

Broad money

Change in terms of trade

Old-age dependency ratio

Consumer price inflation

Per capita GDP growth

Real interest rate

Housing price index

Equity market index

Memorandum items:

Implied long-term offset

High debt

No. of observations

No. of cross-sectional units

Sargan test (overidentification, $p$-value)

First-order autocorrelation ( $p$-value)

Second-order autocorrelation ( $p$-value)

\begin{tabular}{ccc} 
Baseline & 1 & 2 \\
\hline $0.77^{* * *}$ & $0.67 * * *$ & $0.67 * * *$ \\
$(0.023)$ & $(0.030)$ & $(0.031)$
\end{tabular}

$-0.23 * * *$

$-0.29 * * *$

$-0.36 * * *$

$(0.024)$

$(0.031)$

$(0.040)$

$0.09 * *$

$(0.041)$

$\begin{array}{cc}0.00 & 0.00 \\ (0.011) & (0.012) \\ 0.04 * * * & 0.04 * * * \\ (0.014) & (0.016) \\ -0.30 * * * & -0.31 * * * \\ (0.053) & (0.055) \\ 0.02 & 0.04 \\ (0.034) & (0.040) \\ -0.02 & -0.02 \\ (0.033) & (0.035) \\ -0.09 * * * & -0.11 * * * \\ (0.028) & (0.034) \\ -0.01 * * * & -0.01 * * * \\ (0.001) & (0.001) \\ -0.02 * * * & -0.02 * * * \\ (0.004) & (0.004)\end{array}$

$-1.00$

$-0.88$

$-1.09$

Debt $>70.8$

... $\quad \ldots$

270

$\begin{array}{rrr}469 & 290 & 270 \\ 21 & 16 & 16\end{array}$

$\begin{array}{lll}0.05 & 0.99 & 0.99\end{array}$

$\begin{array}{lll}0.00 & 0.00 & 0.00\end{array}$

$\begin{array}{lll}0.07 & 0.67 & 0.70\end{array}$

a) All models are estimated using the Arellano-Bond difference-GMM estimator and include a common intercept (not reported). Standard errors are reported in parentheses. Statistical

b) Net lending is cyclically adjusted.

Source: OECD Economic Outlook database. 
33. A variety of static and dynamic versions of the partial-equilibrium model are also reported in Table A2.2. The estimated offset coefficients are higher in the static models, estimated by pooled least squares, probably due to a lack of control for country-specific effects and inertia, and in the static models estimated by fixed and random effects, and somewhat lower when the dynamic model is estimated by pooled least squares and random effects. ${ }^{27}$ In all cases, however, evidence of a statistically significant private-public offset and inertia in saving rates cannot be rejected. ${ }^{28}$

34. The baseline results are also robust to the elimination of outliers in the sample (not reported). ${ }^{29}$ Changes in private saving behaviour over time do not seem to affect the robustness of the baseline parameter estimates insofar as focusing on the period 1980-2002 to eliminate the influence of the two oil shocks and the collapse of the fixed exchange rate regime does not seem to affect the magnitude of the estimated offset coefficient significantly. ${ }^{30}$ But the estimated private-public offset appears to be higher in magnitude when attention is focused on the period 1990-2002, where area-wide fiscal consolidation, particularly in the second half of the decade, coupled with wealth effects resulting from the asset and housing price cycle, may have played a role.

35. The sensitivity of the baseline results to different definitions of private saving was also assessed. Redefining private saving from the Balance of Payments (BoP), rather than National Accounts, perspective tends to increase the magnitude of the estimated private saving offset, lending stronger, albeit not unequivocal, support of a strict private saving offset. ${ }^{31}$ And this finding does not seem to be overly sensitive to whether net capital transfers are excluded from the definition of private saving. A lower offset coefficient is obtained when attention is focused on household, rather than private, saving. The finding does seem to be somewhat sensitive to the elimination of outliers, suggesting that measurement errors may be particularly pronounced. Measurement problems are due to the difficulty in accurately demarcating the household and corporate sectors, given extensive household ownership of businesses via equity and mutual/pension fund participation, as discussed above. Inclusion of the current account balance among the

27. Fixed-effects regressions are reported for the static model to deal with the presence of country effects, but not for the dynamic model, where the presence of a lagged dependent variable is known to bias parameter estimates. First-differencing also eliminates time-invariant effects.

28. The results obtained with the difference-GMM (preferred estimator) and the Arellano-Bover (1995) system-GMM estimators are qualitatively similar, suggesting that the potential small-sample bias associated with the use or weak instruments in the former may not be important. The system-GMM estimator estimates the equation in levels, using first differences as instruments, and in differences, using lagged levels as instruments.

29. Elimination of a country at a time does not suggest that the baseline offset coefficient is overly sensitive to potential outliers. To test the robustness of the baseline estimate of the private saving offset, the observations corresponding to the top and bottom quartiles of the sample's private saving distribution were excluded, with the estimated offset coefficient being somewhat lower in magnitude relative to the baseline. Likewise, elimination of outliers in the public saving distribution, defined as those observations in the distribution's top and bottom quartiles, does not seem to affect the baseline offset coefficient significantly, although the estimate of the private saving offset is somewhat higher.

30. See Hjelm (2002) and Lambertini and Tavares (2003) for empirical evidence that exchange rate depreciation prior to fiscal consolidation increases its likelihood of success.

31. From the Balance of Payments perspective, private saving can be calculated as the difference between the current account balance (plus total investment) and the general government budget balance (plus public investment) and net capital transfers to non-residents. 
regressors, to proxy for international capital market access and to control for public-foreign saving substitutability, does not seem to affect the estimated private saving offset significantly.

\subsection{Initial conditions and composition effects}

\subsubsection{The role of indebtedness}

36. Initial conditions, gauged by the level of public indebtedness, may affect the magnitude of the private saving offset. High and/or rising indebtedness may raise concern about debt sustainability, which could be interpreted as eliciting a more rapid corrective action on the part of policymakers, increasing the likelihood of fiscal consolidation. ${ }^{32}$ This would, in principle, encourage private saving due to the recognition that restoring fiscal sustainability may require higher taxes. To test the hypothesis that the magnitude of the private saving offset is affected by initial conditions, the cyclically-adjusted budget balance was interacted with a variable indicating the level of the public debt in per cent of GDP.

37. Based on this methodology, offsetting movements in private and public saving appear to be stronger when the debt ratio is below a threshold of about 70 per cent of GDP (Table 1). ${ }^{33}$ As outlined above, there appears to be a somewhat weaker private saving offset at higher levels of indebtedness (above approximately 70 per cent of GDP). The finding, which is robust to the estimation of the saving equation in partial equilibrium (shown in Table 2) and error correction representations, could be attributable to a number of factors. The first may be the association of higher debt with higher inflation during the earlier part of the period, which tended to bias measured public dissaving up and the private saving offset down in high debt countries, by the amount of the "inflation tax": in effect there would be no need to save in anticipation of higher taxation since a tax was already being imposed. Moreover, where debt accumulation becomes unsustainable, concern about rising inflation may even reduce the propensity to save in monetary assets in order to avoid a growing "tax" on money and bond-holders. Higher anticipated inflation encourages consumption on durables, for example, as a means to store wealth, thus reducing the private saving offset, ${ }^{34}$ although that could be partly mitigated by a likely increase in risk premia on interest rates and a rebalancing of portfolios towards inflation-indexed, interest-bearing assets. If these channels were to be explicitly controlled for, expectations of more imminent corrective action would tend to strengthen the private saving offset at high levels of debt.

38. Second, the weaker private saving offset where the debt-to-GDP ratio is high could imply an increased degree of myopia on the part of households. This paradox may result from a perception that highly-indebted governments are also myopic, being expected to continue with deficit finance and defer taxes to the future. In addition, high government indebtedness may crowd out bank credit to the private sector, weakening -- at least over the short term -- the private saving offset of a fiscal contraction because

32. There is a growing body of literature on the effects of debt on fiscal policy, rather than on how it affects private saving responses to changes in fiscal stance. Using US data for the period 1916-95, Bohn (1998) shows that the primary budget balance tends to rise in response to rising indebtedness and that this marginal response is increasing in the debt-to-GDP ratio.

33. This debt level corresponds to the $75^{\text {th }}$ percentile of the sample's distribution, allowing one-quarter of the sample to be within the high range of indebtedness. Countries with gross debt ratios above 70 per cent of GDP include Belgium, since 1980; Canada, since 1990; Greece, since 1990; Ireland, until the mid-1990s, and Italy, during most of the sample period, and more recently Japan. See Nicoletti (1992), for empirical evidence on saving responses to fiscal policy in indebted countries, and Pozzi (2003), for more information on the Belgian experience.

34. This would imply a non-linear inflation effect over and above that picked up by the inflation and interest rate control variables. 
the number of individuals that are credit constrained may increase, making private consumption more sensitive to current, rather than permanent, income. ${ }^{35}$ In fact, as reported below, in the more financiallyderegulated, lower-inflation, and rules-based post-1992 period, more highly-indebted members of the EMU did experience greater tax discounting.

\subsubsection{The role of composition effects: revenues vs. expenditures}

39. The analysis can be extended to decompose public saving into its revenue and expenditure components. Based on the findings reported in Table 3, the OECD experience suggests that, in general, private saving rises only slightly less in response to current expenditure hikes (for a given level of revenue) than to shifts in taxation (for a given level of spending). Specifically, private saving is estimated to rise by about 0.8 per cent of GDP in the long term in response to a tax cut of 1 per cent of GDP, keeping expenditure unchanged, and by about 0.7 per cent in response to an increase in current spending of the same magnitude, keeping the tax take constant. The short-run response of saving to taxation is, however, significantly higher than that to current spending. The results do not point to observable offsetting saving effects with respect to public investment, in line with the arguments advanced above, unless the debt-toGDP ratio is relatively high. The partial-equilibrium representation yields comparable results (not reported), with current revenue (expenditure) being negatively (positively) associated with private saving and the offsetting movements in public investment and private saving being statistically significant only at high levels of indebtedness.

35. See Pozzi et al. (2003), for further discussion and empirical evidence for OECD countries. 
Table 3. Sensitivity of private saving to fiscal stance: composition effects and initial conditions

Dep. Var.: Private saving (in per cent of GDP, National Accounts definition): a

Baseline Debt

level

Private saving

Lagged first difference

Lagged level

Current revenue

Lagged first difference

Lagged level

Current revenue $*$ high debt

Current spending

Lagged first difference

Lagged level

Current spending * high debt
$-0.87 * * *$

(0.080)
$-0.31 * * *$
(0.066)
0.07
(0.057)
(0.058)

$0.39 * * *$

(0.077)

$0.18 * * *$

(0.041)

(0.080)

$0.23 * * *$

$(0.053)$

$-0.06$

$(0.055)$

Public investment

Lagged first difference

Lagged level

Public investment * high debt

Memorandum item:

Implied long-term offset

Current revenue

$\begin{array}{rr}-0.81 & -1.11 \\ 0.69 & 0.82\end{array}$

Current spending

No. of observations

No. of cross-sectional units

First-order autocorrelation ( $p$-value)

Second-order autocorrelation ( $p$-value)

0.41

0.21

a) All models are estimated using the Arellano-Bond difference-GMM estimator and include a common intercept and the full set of controls: the ratio of broad money to GDP, change in the terms of trade, the old-age dependency ratio, inflation, per capita GDP growth, and the real interest rate (not reported). Standard errors are reported in parentheses. Statistical significance at the 1,5 , and 10 per cent levels is denoted by respectively $(* * *),(* *)$, and $(*)$. Current revenue and expenditure are cyclically adjusted. The null hypothesis of the Sargan tests for overidentifying restrictions is never rejected at classical levels of significance. 
ECO/WKP(2004)20

\section{Appendix 1. EPISODES OF LARGE SWINGS IN FISCAL STANCE}

40. There have been various episodes of large swings in fiscal stance characterised by strong offsetting movements in private saving. Most of these episodes are well documented. ${ }^{36}$

41. Denmark experienced a crisis in 1982, with long-term interest rates at 21 per cent, inflation at 10 per cent, and the general government deficit at more than 8 per cent of GDP. The general government gross debt-to-GDP ratio increased by almost 50 per cent during 1980-82, to nearly 70 per cent of GDP. The government adopted a draconian fiscal consolidation programme, curbing the growth of real government consumption, cutting back public investment, and raising taxes. The structural deficit fell by 71/4 per cent of GDP during 1982-87 (Figure A.1). Accompanied by a more credible exchange-rate policy, fiscal restraint resulted in GDP growth of 3.2 per cent per year on average during 1982-86, while private consumption increased by an annual average of 3 per cent. The private saving ratio increased slightly in 1982 but decreased thereafter, reflecting mainly lower saving by households. Housing and equity prices increased sharply, resulting in positive wealth effects, while inflation and long-term nominal interest rates halved.

42. Ireland went through a similar episode in 1981, with the gross public debt ratio attaining 74 per cent of GDP and the fiscal deficit reaching 12.3 per cent of GDP. The government pursued a similar type of fiscal policy as in Denmark, but confidence did not recover. Housing and equity prices declined, and real consumption fell by more than 7 per cent in 1982. A second stabilisation effort, implemented in 1987, was more successful. The cyclically-adjusted budget deficit declined from 8 per cent of trend GDP in 1986 to below 2 per cent in 1989, while gross debt declined substantially after peaking at over 110 per cent of GDP in 1986-87. GDP grew at an annual average rate of 6 per cent during 1986-90. Private saving increased slightly in 1987 but decreased thereafter, reflecting lower saving by households. The first and second stabilisation efforts differed in many respects. In particular, fiscal consolidation relied much more on cuts in expenditure in 1987 and less on tax increases and the exchange rate policy was more credible, which anchored inflation expectations.

43. In contrast with the Danish and Irish episodes, the Swedish experience of 1990-94 has been characterised as a contractionary fiscal expansion, and provides an example of a debt-financed decline in net taxes as public consumption was relatively stable as a share of trend GDP. Sweden entered the 1990s with strong public finances: a government surplus of 43/4 per cent of GDP in 1989 and public debt below 50 per cent of GDP and falling. Sweden went through the sharpest recession of its recent history during 1990-93. Automatic stabilisers, which are relatively strong, were allowed to work in addition to a significant discretionary fiscal loosening, mainly in the form of the tax cuts embedded in the 1991 tax reform, and the bail-out of major banks in 1991-93. The deficit-to-GDP ratio deteriorated by over 15 percentage points ( $81 / 2$ percentage points in cyclically-adjusted terms). Gross public debt increased to over 80 per cent of GDP. The fiscal expansion was associated with a sharp contraction in economic

36. See Giavazzi and Pagano (1990), Leibfritz et al. (1994), Giavazzi and Pagano (1996), and European Commission (2003), for more information. 
Figure A.1. Episodes of large swings in fiscal stance in selected OECD countries Per cent of GDP, deviation from turning point

— Government balance (ca) _— Private saving

\section{A. Fiscal contractions}

United States, $\mathrm{t}=1992$

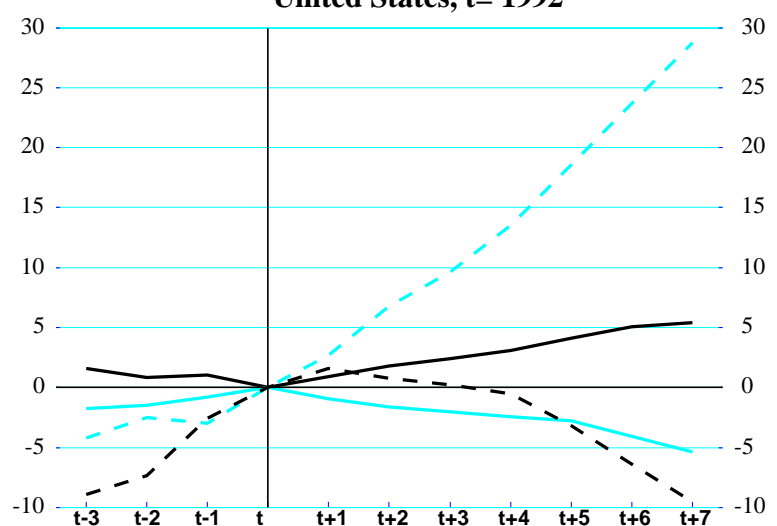

Denmark, $t=1982$

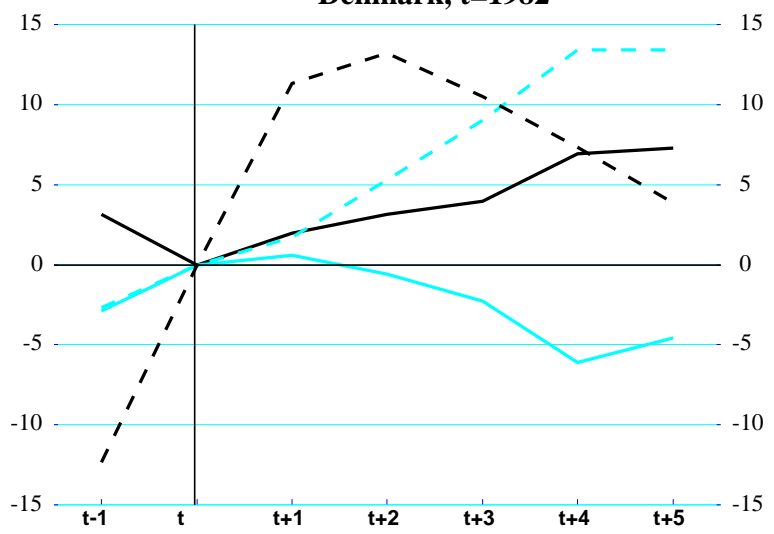

Ireland, $\mathrm{t}=1986$

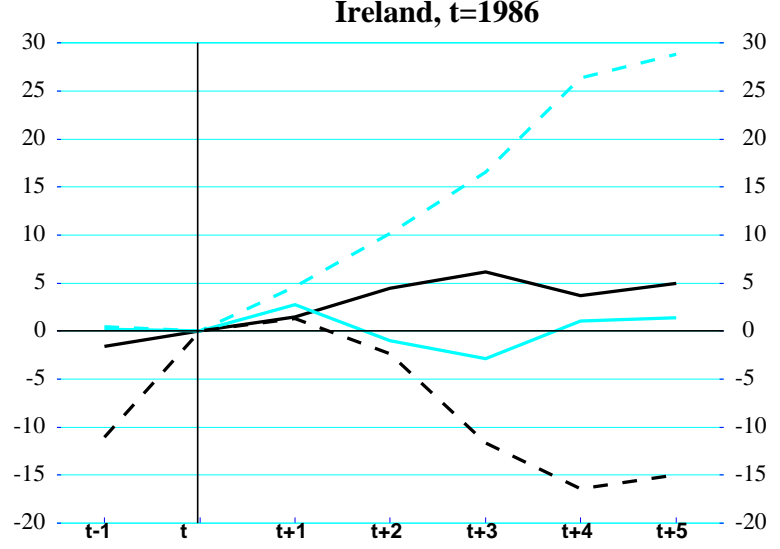

Source: OECD Economic Outlook 74 Database.
- - Real GDP (index)

- - General government gross debt (right scale)

B. Fiscal expansions

Japan, $t=1991$

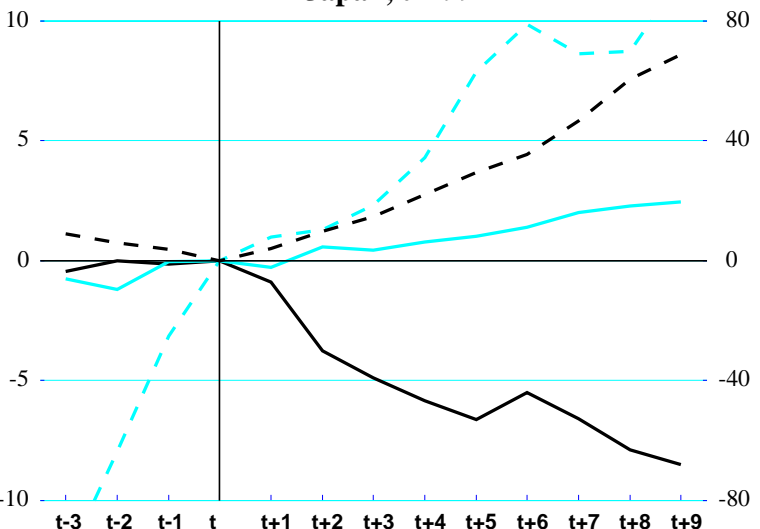

Sweden, $t=1989$

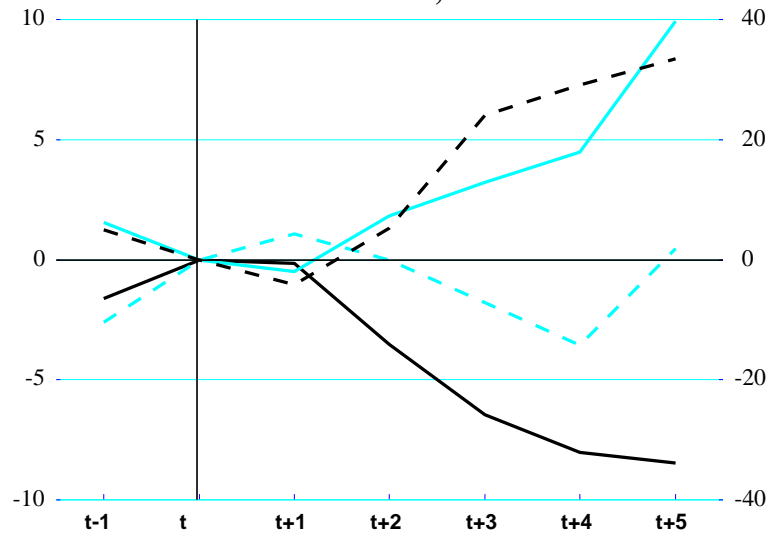


activity. GDP fell by 0.9 per cent a year on average from 1989 to 1993 and unemployment increased sharply. Real housing prices declined by more than 20 per cent over the same period, reflecting significantly high after-tax real interest rates. Private, particularly household, saving increased as a share of GDP in the wake of these events.

44. The Japanese economy went into recession in $1991 .^{37}$ To stabilise the economy, the Japanese government introduced a series of stimulus packages over the 1990s, starting with a first set of public works in 1992-93. A tax cut (supposed to be reversed in 1997) and public spending expansion followed in 1995. The overall government balance deteriorated from a surplus of close to 2 per cent of GDP at the beginning of the 1990s to a deficit of more than 7 per cent in 2000, most of this attributed to non-cyclical factors. Private saving as a share of GDP increased by more than 5 percentage points over the same period. GDP growth fell from over 5 per cent in 1989-90 to close to zero per cent in 1993. The average growth rate over the 1990s reached only 1.1 per cent, resulting in a gradual increase in unemployment. The private saving offset may, however, also have reflected the collapse of the bubble economy, which resulted in significant bad debts and other financial-sector difficulties, and this may have contributed to the strong pick-up in business saving in Japan in the 1990s (net borrowing declined substantially). ${ }^{38}$ These wealth effects occurred independently of fiscal policy, but there is little evidence that the expenditure (publicworks)-based expansion provided a platform for a countervailing increase in wealth.

45. The United States experienced a prolonged period of economic growth in the 1990s, against the backdrop of a strong increase in stock price. The general government budget balance improved strongly in cyclically-adjusted terms, based on expenditure restraint and soaring tax receipts, and gross public debt was reduced from 75 per cent of GDP in 1992 to below 60 per cent of GDP in 2000. Private saving declined significantly over the same period, due to lower saving by both households and businesses, and this has been related to the substantial rise in financial wealth during the period. Rapid productivity growth and low interest rates were causal factors, but fiscal retrenchment may have been an important facilitating factor, by making room for the more productive use of capital. ${ }^{39}$ However, about half of the decline in personal saving in the United States since the late 1980s is estimated to be due to households spending stock market capital gains, and another 30 per cent can be explained by the treatment of pensions and capital gains taxes. ${ }^{40}$

37. See Yoshino and Sakakibara (2003), for more information.

38. See, for example, OECD (2003c). Also, Ihori and Sato (2002) find that perfect debt neutrality is not valid in Japan in the 1990s, but argue that individuals are concerned with long-run effects of fiscal policy and behave at least in part in a Ricardian fashion. Similarly, Kuttner and Posen (2001) find that exogenous fiscal policy shocks had pronounced real effects in Japan in the 1990s, although some offsetting confidence effects may have played a role.

39. See, for example, Lusardi et al. (2001), for more information.

40. Gale and Sabelhaus (1999) point out that if capital gains are counted as private saving, the household saving rate was at its highest level in forty years in the late 1990s, not its lowest. 


\section{Appendix 2 \\ DESCRIPTIVE STATISTICS AND ROBUSTNESS ANALYSIS TABLES}

Table A2.1. Descriptive Statistics ${ }^{a}$

\begin{tabular}{|c|c|c|c|c|c|c|}
\hline & Mean & $\begin{array}{l}\text { Standard } \\
\text { deviation }\end{array}$ & Median & Maximum & Minimum & $\begin{array}{l}\text { No. } \\
\text { Obs. }\end{array}$ \\
\hline \multicolumn{7}{|l|}{ National saving (in per cent of GDP) } \\
\hline National Accounts definition & 17.8 & 5.1 & 17.9 & 38.1 & 5.4 & 529 \\
\hline Balance of payments definition & 21.4 & 4.0 & 21.1 & 33.7 & 12.6 & 621 \\
\hline \multicolumn{7}{|l|}{ Private saving (in per cent of GDP) } \\
\hline National Accounts definition & 18.3 & 5.2 & 18.4 & 31.4 & 3.1 & 529 \\
\hline Balance of payments definition & 22.6 & 5.0 & 22.5 & 38.5 & 8.0 & 506 \\
\hline \multicolumn{7}{|l|}{ Public saving (in per cent of GDP) } \\
\hline National Accounts definition & -0.1 & 4.1 & -0.2 & 16.5 & -10.2 & 653 \\
\hline \multicolumn{7}{|l|}{ Household saving (in per cent of disposable income) } \\
\hline National Accounts definition & 12.0 & 9.9 & 10.9 & 59.9 & -12.8 & 615 \\
\hline \multicolumn{7}{|l|}{ Other fiscal aggregates (in per cent of GDP) ${ }^{b}$} \\
\hline Net lending & -2.5 & 4.3 & -2.5 & 15.0 & -15.7 & 653 \\
\hline Cyclically-adjusted net lending & -2.8 & 3.7 & -2.4 & 7.8 & -16.4 & 590 \\
\hline Primary budget balance & 0.2 & 3.2 & 0.2 & 12.4 & -12.0 & 653 \\
\hline Cyclically-adjusted primary budget balance & 0.0 & 3.1 & 0.2 & 7.4 & -10.4 & 570 \\
\hline Current revenue & 42.0 & 9.4 & 42.4 & 63.2 & 20.4 & 653 \\
\hline Cyclically-adjusted current revenue & 42.7 & 9.4 & 43.0 & 63.6 & 21.3 & 597 \\
\hline Current expenditure & 42.1 & 10.0 & 42.3 & 69.0 & 16.3 & 658 \\
\hline Cyclically-adjusted current expenditure & 42.9 & 10.0 & 42.8 & 65.1 & 16.7 & 598 \\
\hline Public debt & 57.4 & 27.8 & 55.2 & 147.3 & 0.0 & 613 \\
\hline \multicolumn{7}{|l|}{ Control variables } \\
\hline Broad money (in per cent of GDP) & 61.7 & 19.9 & 57.4 & 134.4 & 24.3 & 634 \\
\hline Change in terms of trade (in per cent) & -0.2 & 4.6 & 0.1 & 24.4 & -25.4 & 672 \\
\hline Old-age dependency ratio (in per cent) & 18.5 & 4.1 & 18.2 & 32.8 & 9.8 & 551 \\
\hline Consumer price inflation (in per cent) & 6.8 & 6.4 & 4.9 & 60.9 & -0.9 & 666 \\
\hline Per capita GDP growth rate (in per cent) & 2.2 & 2.4 & 2.3 & 11.7 & -9.1 & 671 \\
\hline Real interest rate (in per cent, short-term rate) & 2.9 & 3.6 & 3.2 & 11.3 & -17.8 & 615 \\
\hline
\end{tabular}




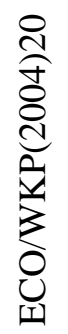

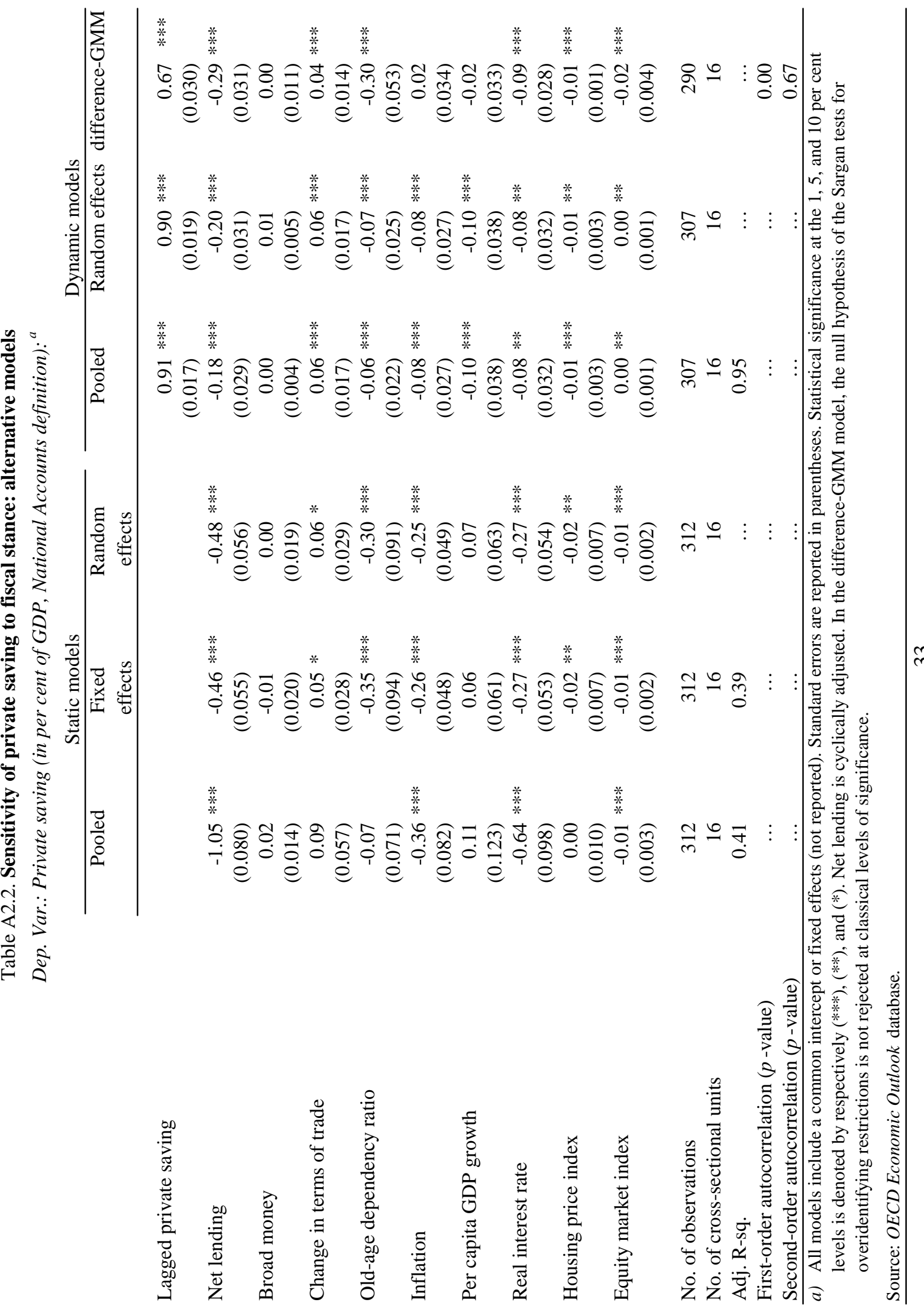




\section{BIBLIOGRAPHY}

ALESINA, A. and S. ARDAGNA (1998), "Tales of fiscal contractions,” Economic Policy, No. 27.

ALESINA, A. and R. PEROTTI (1995), "Fiscal expansions and adjustments in OECD countries," Economic Policy, No. 21.

ALESINA, A., R. PEROTTI and J. TAVARES (1998), "The political economy of fiscal adjustments," Brookings Papers on Economic Activity, Vol. 1998, No. 1.

ALESINA, A., S. ARDAGNA, R. PEROTTI and F. SCHIANTARELLI (2002), "Fiscal policy, profits, and investment," American Economic Review, Vol. 92.

ARELLANO, M. and S.R. BOND (1991). "Some Tests of Specification for Panel Data: Monte Carlo Evidence and an Application to Employment Equations", Review of Economic Studies, Vol. 58.

ARELLANO, M. and O. BOVER (1995). "Another Look at the Instrumental-Variable Estimation of Error Components Models", Journal of Econometrics, Vol. 68.

AUERBACH, A.J. (1985), "Saving in the US: some conceptual issues," in P.H. Hendershott (ed.), The level and composition of Household Saving, Cambridge.

BARRO, R. (1974), “Are government bonds net wealth?,” Journal of Political Economy, Vol. 82.

BARRO, R. (1989), "The Ricardian approach to budget deficits," Journal of Economic Perspectives, Vol. 3.

BLANCHARD, O. (1990), "Comment on Giavazzi and Pagano (1990)," in O. Blanchard and S. Fisher (eds.), NBER Macroeconomics Annual.

Blondal, S., S. Field, and N. Girouard (2002), "Investment in human capital through post-compulsory education and training: selected efficiency and equity aspects," OECD Economics Department Working Papers, No. 333.

BOHN, H.(1998), “The behaviour of US public debt and deficits", Quarterly Journal of Economics, Vol. 113.

BOONE, L., N. GIROUARD and I. WANNER (2001), "Financial market liberalisation, wealth, and consumption," OECD Department of Economics Working Papers, No. 308.

CALLEN, T. and C. THIMANN (1997), "Empirical determinants of household saving: evidence from OECD countries", IMF Working Paper, No. 97/181.

CARROLL, C.D. (1997), "Buffer-stock saving and the life cycle/permanent income hypothesis", Quarterly Journal of Economics, Vol. 112.

COTIS, J.P., J. COPPEL and L. DE MELLO (2004), "Is the U.S. prone to over-consumption?", presented at the Federal Reserve Bank of Boston Economic Conference on the Macroeconomics of Fiscal Policy, Chatham, Massachusetts, June 14-16. 
DE SERRES, A. and F. PELGRIN (2003), "The decline in private saving rates in the 1990s in OECD countries: how much can be explained by non-wealth determinants?," OECD Economic Studies, No. 36 .

EDWARDS, S. (1996), "Why are Latin America's saving rates so low: an international comparative analysis", Journal of Development Economics, Vol. 51.

ELMENDOF, D.W. and N.G. MANKIW (1999), "Government debt", in J.B. Taylor and M. Woodford (eds.) Handbook of Macroeconomics, Amsterdam: North-Holland.

EUROPEAN COMMISSION (2003), "Public finances in the EMU 2003”, No. 3.

GALE, W.G. and J. SABELHAUS (1999), "Perspectives on the household saving rate", Brookings Papers on Economic Activity, Vol. 1999.

GIAVAZZI, F. and M. PAGANO (1990), "Can severe fiscal contractions be expansionary? Tales of two small European countries," NBER Macroeconomics Annual.

GIAVAZZI, F. and M. PAGANO (1996), "Non-Keynesian effects of fiscal policy changes: international evidence and Swedish experience," Swedish Economic Policy Review, Vol. 3.

GIAVAZZI, F., T. JAPPELLI and M. PAGANO (2000), "Searching for non-linear effects of fiscal policy: evidence from industrial and developing countries," European Economic Review, Vol. 44.

HAQUE, N., M.H. PESARAN and S. SHARMA (1999), "Neglected heterogeneity and dynamics in cross-country savings regressions", IMF Working Paper, No. 09/128.

HEMMING, R., M. KELL and S. MAHFOUZ (2002), "The effectiveness of fiscal policy in stimulating economic activity - a review of the literature", IMF Working Paper, No. 02/208.

HJELM, G. (2002), "Effects of fiscal contractions: the importance of preceding exchange rate movements", Scandinavian Journal of Economics, Vol. 104.

IHORI, T. and M. SATO (2002), Government deficit and fiscal reform in Japan (eds.), Kluwer Academic Publications.

IMF (INTERNATIONAL MONETARY FUND) (2003), “United States of America: Selected Issues”, IMF Country Report, No. 03/245.

KUTTNER, K.N. and A.S. POSEN (2001), "Passive savers and fiscal policy effectiveness in Japan", paper prepared for the CEPR-CIRJE-NBER Conference on Issues in Fiscal Adjustment, 13-14 December, Tokyo, Japan.

LAMBERTINI, L. and J. TAVARES (2003), "Exchange rates and fiscal adjustments: evidence from the OECD and implications for EMU," Boston College Working Papers in Economics, No. 576.

LEIBFRITZ, W., D. ROSEVEARE and P. VAN DEN NOORD (1994), "Fiscal policy, government debt and economic performance", OECD Economic Department Working Papers, No. 144.

LOAYZA, N., K. SCHMIDT-HEBBEL and L. SERVEN (2000), "What drives private saving across the world?", Review of Economics and Statistics, Vol. 82. 
LUSARDI, A., J. SKINNER and S. VENTI (2001), "Saving puzzles and saving policies in the United States", NBER Working Paper, No. 8237.

MASSON, P.R., T. BAYOUMI and H. SAMIEI, 1998, "International evidence on the determinants of private saving," The World Bank Economic Review, Vol. 12.

MANKIW, N.G. (2000), "The savers-spenders theory of fiscal policy," AEA Papers and Proceedings, Vol. 90.

McDERMOTT, C.J. and R.F. WESCOTT (1996), “An empirical analysis of fiscal adjustments”, IMF Staff Papers, Vol. 43.

NICOLETTI, G. (1992), "Is tax-discounting stable over time?", Oxford Bulletin of Economics and Statistics, Vol. 54.

OECD (2001a), OECD Economic Survey of the United States, Paris.

OECD (2001b), "Investment in human capital through post-compulsory education and training," paper: http://www.oecd.org/dataoecd/47/31/24477912.doc.

OECD (2002), OECD Economic Outlook, December, Paris.

OECD (2003a), OECD Economic Outlook, December, Paris.

OECD (2003b), "Final Recommendations on the treatment of taxes on holding gains in the SNA", STD/NAES(2003)1.

OECD (2003c), OECD Economic Survey of Japan, Paris.

PEROTTI, R. (1999), "Fiscal policy in good times and bad" Quarterly Journal of Economics, Vol. 114.

POZZI, L. (2003), "Tax discounting in a high-debt Economy", Oxford Bulletin of Economics and Statistics, Vol. 65.

POZZI, L., F. HEYLEN and M. DOSSCHE (2003), "Government debt and the excess sensitivity of private consumption to current income: an empirical analysis for OECD countries", Working Papers of Faculty of Economics and Business Administration, No. 02.155, Ghent University.

RICCIUTI, R. (2003), “Assessing Ricardian equivalence”, Journal of Economic Surveys, Vol. 17.

SEATER, J.J. (1985), “Does government debt matter?”, Journal of Monetary Economics, Vol. 16.

SEATER, J.J. (1993), "Ricardian equivalence”, Journal of Economic Literature, Vol. 31.

YOSHINO, N. and E. SAKAKIBARA (2003), "The current state of the Japanese economy and remedies", revised version of paper presented for the Asian Economic Panel meeting held in Cambridge, Massachusetts, 26-27 April.

ZAGHINI, A. (1999), "The economic policy of fiscal consolidations: the European experience", Banca d'Italia, Temi di Discussione, No. 355. 


\section{WORKING PAPERS}

The full series of Economics Department Working Papers can be consulted at www.oecd.org/eco/Working_Papers/

396. The impact of exchange rate regimes on real exchange rates in South America, 1990-2002 (June 2004) Anne-Laure Baldi and Nanno Mulder

395. How Market Imperfections and Trade Barriers Shape Specialisation: South America vs. OECD (June 2004) Joaquim Oliveira Martins and Tristan Price

394. Housing Markets, Wealth and the Business Cycle (June 2004) Pietro Catte, Nathalie Girouard, Robert Price and Christophe André

393. Long-Term Budgetary Implications of Tax-Favoured Retirement Saving Plans (June 2004) Pablo Antolin, Alain de Serres and Christine de la Maisonneuve

392. Enhancing Income Convergence in Central Europe after EU Accession (June 2004) Patrick Lenain and Lukasz Rawdanowicz

391. Asset Price Cycles, “One-Off” Factors and Structural Budget Balances (June 2004) Nathalie Girouard and Robert Price

390. Channels for Narrowing the US Current Account Deficit and Implications for Other Economies (May 2004) Anne-Marie Brook, Franck Sédillot and Patrice Ollivaud

389. Product Market Competition and Economic Performance in Norway (May 2004) Jens Høj and Michael Wise.

388. Product Market Competition and Economic Performance in Sweden (May 2004) Deborah Roseveare, Martin Jørgensen and Lennart Goranson

387. Product Market Competition and Economic Performance in Japan (May 2004) Jens Høj and Michael Wise

386. Migration and Integration of Immigrants in Denmark (May 2004) Deborah Roseveare and Martin Jørgensen

385. Factors Driving Risk Premia (April 2004) Torsten Sløk and Mike Kennedy

384. Rationalising Public Expenditure in the Slovak Republic (March 2004) Rauf Gönenç and Peter Walkenhorst

383. Product Market Competition and Economic Performance in Switzerland (March 2004) Claude Giorno, Miguel Jimenez and Philippe Gugler

383. Concurrence sur les Marchés de Produits et Performance Économique en Suisse (Mars 2004) Claude Giorno, Miguel Jimenez and Philippe Gugler

382. Differences in Resilience between the Euro-Area and US Economies (March 2004) Aaron Drew, Mike Kennedy and Torsten Sløk

381. Product Market Competition and Economic Performance in Hungary (March 2004) Carl Gjersem, Philip Hemmings and Andreas Reindl 


\section{ECO/WKP(2004)20}

380. Enhancing the Effectiveness of Public Spending: Experience in OECD Countries (February 2004) Isabelle Joumard, Per Mathis Kongsrud, Young-Sook Nam and Robert Price

379. Is there a Change in the Trade-Off between Output and Inflation at Low or Stable Inflation Rates? Some Evidence in the Case of Japan (February 2004) Annabelle Mourougane and Hideyuki Ibaragi

378. Policies bearing on product market competition and growth in Europe (January 2004) Carl Gjersem

377. Reforming the Public Expenditure System in Korea (December 2003) Young-Sook Nam and Randall Jones

376. Female Labour Force Participation: Past Trends and Main Determinants in OECD Countries (December 2003) Florence Jaumotte

375. Fiscal Relations Across Government Levels (December 2003) Isabelle Joumard and Per Mathis Kongsrud

374. Health-Care Systems: Lessons from the Reform Experience (December 2003) Elizabeth Docteur and Howard Oxley

373. Non-Tariff Measures Affecting EU Exports: Evidence from a Complaints-Inventory (December 2003) Peter Walkenhorst and Barbara Fliess

372. The OECD Medium-Term Reference Scenario: Economic Outlook No. 74 (November 2003) Peter Downes, Aaron Drew and Patrice Ollivaud

371. Coping with Ageing: A Dynamic Approach to Quantify the Impact of Alternative Policy Options on Future Labour Supply in OECD Countries

(November 2003) Jean-Marc Burniaux, Romain Duval and Florence Jaumotte

370. The Retirement Effects of Old-Age Pension and Early Retirement Schemes in OECD Countries (November 2003) Romain Duval

369. Policies for an Ageing Society: Recent Measures and Areas for Further Reform (November 2003) Bernard Casey, Howard Oxley, Edward Whitehouse, Pablo Antolin, Romain Duval, Willi Leibfritz

368. Financial Market Integration in the Euro Area (October 2003) Carl Gjersem

367. Recent and Prospective Trends in Real Long-Term Interest Rates: Fiscal Policy and Other Drivers (September 2003) Anne-Marie Brook

366. Consolidating Germany's finances: Issues in public sector spending reform (September 2003) Eckhard Wurzel

365. Corporate Taxation of Foreign Direct Investment Income 1991-2001 (August 20030) Kwang-Yeol Yoo

364. Indicator Models of Real GDP Growth in Selected OECD Countries (July 2003) Franck Sédillot and Nigel Pain

363. Post-Crisis Change in Banking and Corporate Landscapes - the Case of Thailand (July 2003) Margit Molnar 